\title{
Pharmacogenomic Characterization in Bipolar Spectrum Disorders
}

\author{
Stefano Fortinguerra ${ }^{1,2} \odot$, Vincenzo Sorrenti $1,2,3 \oplus$, Pietro Giusti ${ }^{2}$, Morena Zusso ${ }^{2}$ and \\ Alessandro Buriani 1,2,*(D) \\ 1 Maria Paola Belloni Center for Personalized Medicine, Data Medica Group (Synlab Limited), 35131 Padova, \\ Italy; stefano.fortinguerra@gmail.com (S.F.); vincenzosorrenti88@gmail.com (V.S.) \\ 2 Department of Pharmaceutical \& Pharmacological Sciences, University of Padova, 35131 Padova, Italy; \\ pietro.giusti@unipd.it (P.G.); morena.zusso@unipd.it (M.Z.) \\ 3 Bendessere $^{\mathrm{TM}}$ Study Center, Solgar Italia Multinutrient S.p.A., 35131 Padova, Italy \\ * Correspondence: alessandro.buriani@gmail.com
}

Received: 25 November 2019; Accepted: 19 December 2019; Published: 21 December 2019

\begin{abstract}
The holistic approach of personalized medicine, merging clinical and molecular characteristics to tailor the diagnostic and therapeutic path to each individual, is steadily spreading in clinical practice. Psychiatric disorders represent one of the most difficult diagnostic challenges, given their frequent mixed nature and intrinsic variability, as in bipolar disorders and depression. Patients misdiagnosed as depressed are often initially prescribed serotonergic antidepressants, a treatment that can exacerbate a previously unrecognized bipolar condition. Thanks to the use of the patient's genomic profile, it is possible to recognize such risk and at the same time characterize specific genetic assets specifically associated with bipolar spectrum disorder, as well as with the individual response to the various therapeutic options. This provides the basis for molecular diagnosis and the definition of pharmacogenomic profiles, thus guiding therapeutic choices and allowing a safer and more effective use of psychotropic drugs. Here, we report the pharmacogenomics state of the art in bipolar disorders and suggest an algorithm for therapeutic regimen choice.
\end{abstract}

Keywords: personalized medicine; bipolar disorder; antipsychotics; mood stabilizers; pharmacogenomics

\section{Introduction}

One important and recent development in the area of mood disorders is the recognition that many patients initially suspected suffering from major depressive disorder suffer instead from a form of bipolar disorder (BD) [1]. Symptomatic bipolar disorder patients are more frequently in the depressive condition rather than in hypomanic, manic, or mixed states [1-3]. As a consequence, such patients can be improperly diagnosed as suffering from major depression and prescribed antidepressants instead of the lithium, atypical antipsychotics, or antiepileptic-type mood stabilizers normally used to treat bipolar spectrum disorders [2,3]. Up to $50 \%$ of the patients once identified as suffering from unipolar depression are now recognized to be suffering from a bipolar spectrum disorder [1-3]. Antidepressant treatment of unrecognized bipolar patients can increase the cyclical nature of the mood disorder, mixed states, and conversion to hypomania and mania, and can also contribute to increase suicide in younger patients ( $<25$ years) [4-6]. The World Mental Health Survey Initiative estimated a 12 month and total lifetime prevalence of $1.5 \%$ and $2.4 \%$, respectively, for bipolar disorder I, bipolar disorder II, and subthreshold BD [5,7]. Most people are in their teens or early twenties when bipolar disorder symptoms begin. The diagnosis of one of the various bipolar spectrum disorders is very complex, especially during the early disease stages. It is estimated that only $20 \%$ of patients with one of the bipolar spectrum disorders associated with depressive episodes are diagnosed and treated correctly 
within one year, with a 5-10 years delay typical between the onset of symptoms and a BD diagnosis [8]. The main problem in making a diagnosis is distinguishing between bipolar I and II disorders from unipolar depression, especially when patients do not have a clear history of episodes of hypomania or mania.

The physiopathology of manic-depressive illness (MDI), or bipolar disorders (BPD) has not been completely clarified. No objective biological marker is available to determine with precision the state of the disease. However, twins, family, and adoption studies have highlighted the association of genetic components with the condition. First-degree relatives of subjects suffering from bipolar disorders are about seven times more likely to develop the disease compared to the general population, while the heritability of bipolar I disorder has been recently estimated at 0.73 [9]. Unipolar depression has been reported as the main misdiagnosis in patients affected by bipolar II disorder, as these patients do not have episodes of complete mania and have mainly depressive episodes, as opposed to hypomania [5,7]. According to the current diagnostic criteria, the distinction of a depressed patient between unipolar major depressive disorder and bipolar spectrum disorder is not simple and is solely entrusted to the clinic. As for other psychiatric conditions, biological parameters are lacking, although some molecular processes conceivably associated with bipolar conditions have been suggested, particularly CNS serotonergic pathway alterations $[10,11]$. HTR2A gene variations have been shown to affect serotonergic receptors, making them hypersensitive to serotonin. When triggered, these hypersensitive receptors could abnormally stimulate glutamatergic transmission Figure 1 [12-14], thus contributing to the induction of states of mania, agitation, and anxiety. Therefore, the use of serotonergic antidepressant therapies can lead to the degeneration of a bipolar disorder spectrum condition [2,3,7]. Unrecognized bipolar patients carrying such genetic mutations have a higher risk of developing a full-blown bipolar condition when receiving serotonergic antidepressants, and should avoid the use of these drugs [15]. 


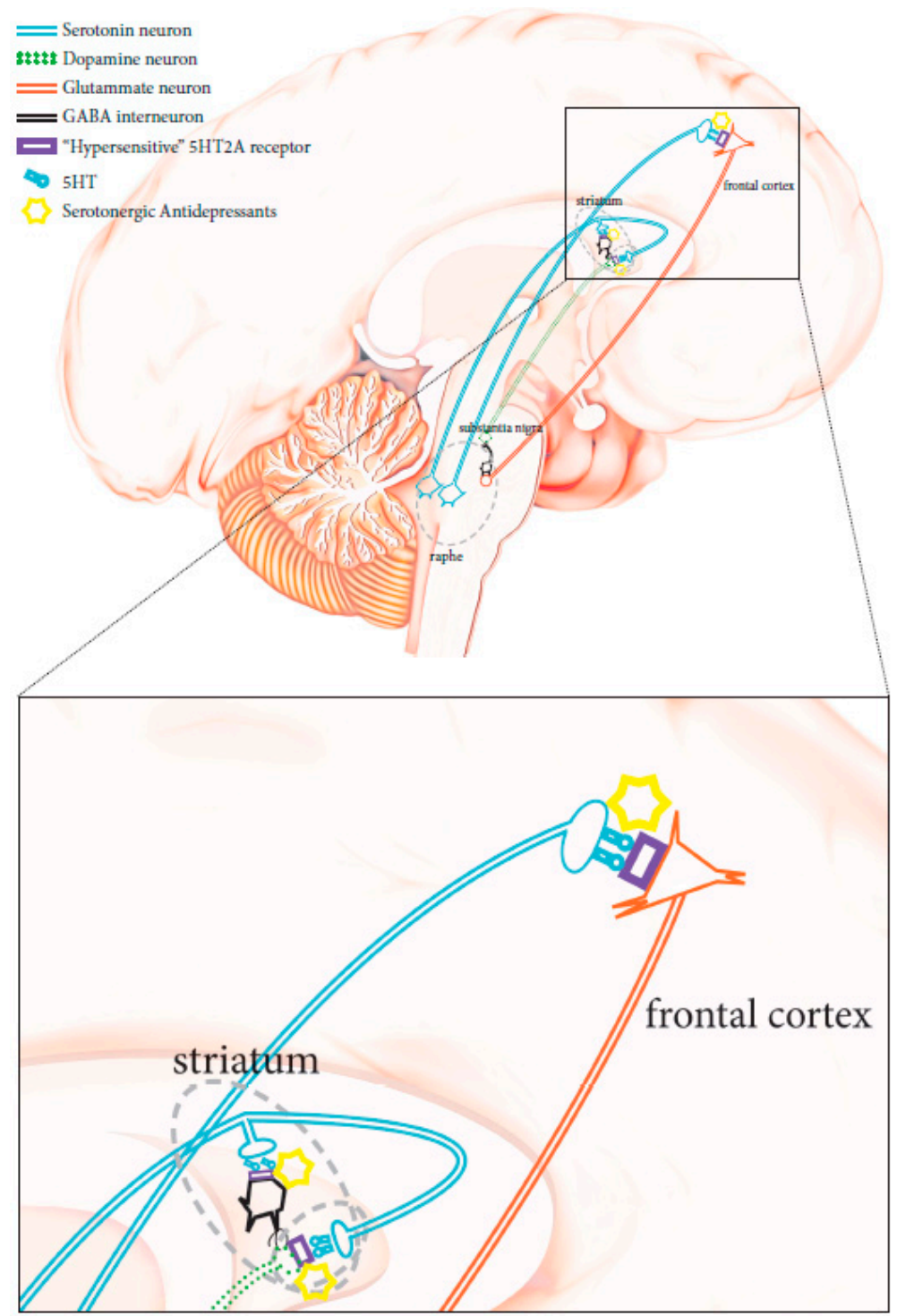

Figure 1. Schematic diagram showing neuronal CNS pathways involved in mania-inducing side effects caused by the administration of a serotoninergic antidepressant when HTR2A is mutated (see text for more details).

\section{Clinical Classification of Bipolar Spectrum Disorders}

In general, bipolar disorders are mood disorders that, unlike depressive disorders, which are characterized by a single polarity, present manic or hypomanic episodes alternating with depressive episodes. They are generally divided into:

- $\quad$ Bipolar I disorder (BDI): The characteristic that primarily characterizes this condition is alternating manic and depressive episodes. BDI is characterized by the appearance of one or more manic or mixed episodes (an overt phase of mania concomitant with a full-blown phase of depression) lasting at least a week. Patients with BDI can also experience episodes of major depression.

- Bipolar II disorder (BDII): This condition is characterized by alternating depressive and hypomanic episodes. Type II bipolar disorder is a mental disease similar to type I bipolar disorder, with moods that cycle between highs and lows, although in BDII the "highs" never reach a complete mania state (hypomania). Subjects with bipolar II disorder suffer more frequently from depressive episodes than from hypomania. Given that hypomania can be confused with normal happiness or even normal functioning, bipolar II disorder can often be misdiagnosed as a unipolar depression. 
- Cyclothymia: This condition is characterized by the alternation of mild depressive episodes and mild hypomanic episodes. In cyclothymia, a person has hypomania (as in bipolar II disorder) that frequently alternates with short periods of mild depression. When present, however, the symptoms of depression do not last long.

- Bipolar disorder not otherwise specified (more recently labeled "not elsewhere classified"): in bipolar disorder not elsewhere classified, people have symptoms of mania or hypomania that are too low or too brief to meet the diagnostic criteria for a syndrome.

Currently, the diagnostic characterization of bipolar spectrum disorders is based mostly on clinical observations, family history, and collection of personal information from those closest to the patient [2]. Symptoms suggesting that depression may be part of a bipolar disorder include increased sleep duration, psychomotor retardation, hyperphagia, psychotic symptoms, anxiety, suicidal ideation, and emotional lability during episodes [2,3]. Other signs that may orient diagnosis towards a bipolar depression are related to the course of the disease, including a high frequency of depressive symptoms, an early age of onset, a high number of sick days, and a sudden symptomatic reduction or disappearance $[2,5]$. The response to antidepressant treatment can also suggest a bipolar depression, such as a sequence of failures with antidepressants and the appearance of side effects like anxiety, agitation, and insomnia [2,3,5].

In the DSM-5 [16], bipolar disorders and related conditions have been distinguished from depressive disorders and relocated between psychotic and depressive disorders, as an intermediate group of conditions in terms of genetics, family history, and symptomatology. Conditions classified as bipolar disorders comprise a range of diagnostic subgroups that can be characterized by the severity of the mood alterations experienced in the acute phase [5].

\section{Pharmacological Treatments of Bipolar Spectrum Disorders}

Before the advent of lithium, common treatments for bipolar patients were solanaceae alkaloids, bromides, and, starting from the early 1900s, barbiturates. The efficacy of lithium salts in the treatment of mania was postulated in 1800s [17]. The antimanic effect was later demonstrated in the 1950s, and it was only in the late 1960s that its effectiveness was demonstrated in bipolar disorder for the prophylaxis of manic-depressive episodes [18]. However, the FDA (US Food and Drug Administration) only released the authorization for its antimanic use in 1978 [19], limited to maintenance/prophylaxis of manic-depressive episodes. In 1995, the FDA approved the anticonvulsant valproic acid for its antimanic use. At the same time, the antiepileptic carbamazepine was introduced for the treatment of bipolar disorder, with approval from both the FDA and NICE (National Institute for Health and Care Excellence). Since 2000, the FDA has approved several atypical antipsychotic drugs (AADs) for their antimanic action (quetiapine, aripiprazole, olanzapine, risperidone, ziprasidone, etc.), or for their antidepressant action (lurasidone, quetiapine). Finally, lamotrigine, a more recent antiepileptic drug, has been approved in bipolar disorder for the prevention of depressive episodes [20-22].

\subsection{Lithium}

Lithium is used to decrease the recurrence of manic episodes, but it is also indicated for depressive episodes, although to a lesser extent [5]. Even though lithium has been used in the treatment of bipolar disorders for almost 60 years, its mechanism of action has not been fully clarified [23]. Some molecular steps have been implicated along the signal transduction cascade activated by neurotransmitter receptors, such as $\mathrm{G}$ proteins and phosphatidyl inositol. More recently, gene expression regulation of growth factors and neuronal plasticity has been associated with lithium activity via components of signal transduction, including protein kinase C and GSK3 $[5,23,24]$. Based on these and other putative molecular associations of the lithium pathways, several studies have been carried out in order to identify potential genetic lithium response predictors [25]. 


\subsection{Antiepileptics as Mood Stabilizers}

Based on the theory that the recurrence of manic episodes can expose the subject to further manic episodes (kindling), a logical parallelism has been drawn with epilepsy, where the appearance of repeated epileptic seizures exposes the subject to further seizures $[5,26,27]$. Several antiepileptics are often prescribed to treat bipolar disorders, some more effectively than others [26,27].

\subsubsection{Valproic Acid}

Valproate is recommended in long-term treatment to prevent mania recurrence in bipolar disorder. It is also used in the acute phase of mania, although its preventive activity has not been adequately clarified in this context [28]. Like lithium, valproic acid can be administered once a day with other mood stabilizers at doses that correspond to the lower limit of the therapeutic range, to enhance tolerability and therapeutic compliance [29]. As with all antiepileptics, its precise mechanism of action is uncertain. At least three hypotheses have been proposed: inhibition of the voltage-dependent sodium channel, enhancement of GABAergic neurotransmission, and regulation of downstream signal transduction cascades $[28,29]$. To explain its mood-stabilizing activity in mania, it has been hypothesized that valproate acts by reducing the excessive stimulation of neurotransmission, inhibiting the ionic flow through the voltage-dependent sodium channels (VSSC) [28]. No specific molecular site has been identified, but the drug may alter the phosphorylation of sodium channels, thus modifying their sensitivity. When less sodium enters the neuron, there is a reduction in glutamate release and therefore excitatory neurotransmission [28-30]. Others have hypothesized that valproate could enhance GABA activity by decreasing its re-uptake, increasing its release, or slowing its metabolic degradation. Although it remains unknown exactly how the enhancement of GABAergic tone is achieved, it is believed that this may explain the antimanic effect of valproic acid [28]. More recently, further mechanisms have been proposed for valproate that could explain its activity. Valproate can inhibit GSK3, but it can act on other molecular targets too; it can inhibit MARCKS (substrate of miranolated kinase $C$ rich in alanine) as well as protein kinase $C$ (PKC), and can activate various signals that promote long-term neuroprotection, such as BCL2, GAP43, ERK, and others [28-30].

\subsubsection{Carbamazepine}

Carbamazepine was the first antiepileptic with demonstrated effectiveness for mania in bipolar disorder [5,31,32], although it did not formally receive FDA approval. It is hypothesized that carbamazepine acts by blocking the voltage-dependent sodium channels (VSSC), possibly at the VSSC subunit level within the channel [33].

\subsubsection{Lamotrigine}

Lamotrigine acts as a mood stabilizer and it is used in prevention of depression and mania, although this use has not been approved by FDA in bipolar depression. Nonetheless, in many guidelines on treatment of bipolar depression, this drug is preferred to antidepressants as a first-line drug [5,34]. The reduction of excitatory-type glutamatergic neurotransmission may represent the specific mechanism of action of lamotrigine [35]. Some other antiepileptic drugs, like gabapentin, topiramate, oxcarbazepine/eslicarbazepine, and pregabalin, some calcium channel blockers of type L (e.g., dihydropyridine), and riluzole, are sometimes prescribed in "experimental" treatments for symptoms associated with bipolar disorder [5].

\subsection{Atypical Antipsychotics}

Atypical antipsychotics have been shown to be effective for the main non-psychotic symptoms of mania and for the prevention of recurrence of mania. Currently, they are the most effective therapeutic option for bipolar disorder, along with most antiepileptics and lithium $[5,36]$. The mechanism of action of atypical antipsychotics in bipolar disorder is not yet fully understood, but the prevailing hypothesis 
is that antagonism or partial agonism of D2 receptors could explain the reduction of manic psychotic symptoms. Moreover, the 5HT2A receptor (5HT2AR) antagonism and partial agonism of 5HT1A receptors could be responsible for the reduction of manic and non-psychotic depressive symptoms observed with some atypical antipsychotics. This may be achieved through the downregulation of the glutamatergic system affecting pyramidal neurons. Given that hyperactivity of the glutamatergic system, depending on the neuronal circuit involved, can be associated with both manic and depressive symptoms, these antipsychotics can be effective in reducing both types of symptoms. Other mechanisms have also been hypothesized to explain why some atypical antipsychotics improve the symptomatic picture of the depressive phase of bipolar disorder. All these mechanisms are based on the ability of some atypical antipsychotics to increase serotonin, dopamine, and norepinephrine levels, while reducing those of glutamate $[37,38]$. Atypical antipsychotics are indicated in schizophrenia, and most of them also in mania, but quetiapine is the only one approved for bipolar conditions, while lurasidone has only been tested $[39,40]$.

\subsection{Benzodiazepines}

Although the use of these drugs as mood stabilizers has not been formally approved, benzodiazepines represent a treatment of considerable value, especially during emergencies. Their prompt administration can provide an immediate sedative effect and provide precious time, unlike mood stabilizers with a slower onset of action. Benzodiazepines are essential drugs for patients who suffer from intermittent episodes of agitation, insomnia, and incipient manic symptoms and require treatment as needed [41].

\subsection{Antidepressants}

Evidence is growing that antidepressants in these disorders not only do not work, but can even exacerbate the condition of some patients with bipolar disorder, leading to mania and hypomania states, destabilizing mood, and increasing cyclicality or even suicidality $[2,3,42,43]$.

Evidence suggests that dysfunctions of glutamate neurotransmission may be implicated in various psychiatric conditions, including bipolar disorders [44,45]. The role of 5HT-mediated glutamatergic activation in BD could explain why the use of antidepressants can exacerbate manic symptoms in bipolar disorders. This hypothesis is still under study, but little doubt remains that antidepressants, tricyclic ones in particular, can trigger manic symptoms in subjects with bipolar spectrum disorders. 5HT2ARs are always postsynaptic and are located in many brain regions. In cortical neurons, they are coupled with $\mathrm{G} \alpha \mathrm{q} / 11$ type $\mathrm{G}$ proteins. The latter activates membrane-bound phospholipase $\mathrm{C}$ beta, leading to cleavage of PIP2 into two messengers, IP3 and diacylglycerol (DAG). This stimulates protein kinase $\mathrm{C}$ (PKC), which in turn controls the function of the main glutamate transporter in CNS, Glutamate transporter-1 [46-48]. In particular, PKC-mediated phosphorylation induces GLT1 transporter downregulation/endocytosis, thus increasing glutamatergic intersynaptic activity [49-52].

\subsection{Associations}

In clinical practice, many subjects suffering from bipolar disorder need to be treated with more than one drug. Effective combinations include the association of valproate or lithium with an atypical antipsychotic. Evidence collected from clinical practice suggests more associations can be utilized, although such suggestions have not been adequately evaluated in controlled clinical trials. Examples include the combination of valproate and lithium, valproate and lamotrigine, lithium and lamotrigine, lithium with quetiapine, and lamotrigine with valproate and lithium. Expert opinions are very divergent when it comes to treating bipolar depression, particularly with antidepressants. Some believe that an antidepressant should not be given in any case, while others simply recommend caution when combining an antidepressant with a mood stabilizer.

In conclusion, current protocols and guidelines for acute mania recommend as first-line treatments lithium, quetiapine, divalproex, asenapine, aripiprazole, paliperidone, risperidone, and cariprazine in 
combination or alone. In bipolar I depression, recommended first-line treatments include quetiapine, lurasidone plus lithium or divalproex, lithium, lamotrigine, lurasidone, or adjunctive lamotrigine. Except for antidepressants, treatment with drugs that have shown efficacy in the acute phase is also recommended in the maintenance phase. For patients initiating or switching drugs in the maintenance phase, the use of monotherapy or combinations of lithium, quetiapine, divalproex, lamotrigine, asenapine, and aripiprazole can be suggested $[5,53]$.

\section{Genetics of Bipolar Spectrum Disorders}

Multiple genetic studies have pointed out that bipolar disorders (BPD) are often heritable conditions, with genetics accounting for $60-85 \%$ of the risk [54,55]. Studies indicate that the risk of recurrence of bipolar disorders in first-degree relatives is about $9 \%$, almost 10 -fold higher than in the general population $[55,56]$. Family studies have also indicated that bipolar I and II disorders have a genetic distinction; the risk of bipolar II disorder among relatives of patients with bipolar II disorder is greater than in relatives of patients with BDI [57-59].

Research on genes that might influence bipolar disorders has been hampered by the phenotypic and genetic complexity of the syndrome, a limited knowledge on its pathogenesis, and by the scarcity of animal models. Linkage studies have highlighted different chromosomal regions as carriers of meaningful genes, but with inconsistent results. It is now generally recognized that the genetic associations of bipolar disorder are linked to many different genes [60,61]. Thus, genetic research in the field has been focused on genome-wide association studies. The application of this approach to $\mathrm{BD}$ since 2007 has allowed the identification of a sizable number of candidate genes, which have since been associated with the disorder in various studies (including DAOA, BDNF, GRIK4, DISC1, TPH2, and SLC6A4) [62]. More recently, the first major BD genome-wide association study by the Psychiatric Genomics Consortium (PGC) Bipolar Disorder Working Group led to the identification of four significant loci at the genomic level. The study analyzed 7481 BD patients and compared them to 9250 controls. Three subsequent meta-analyses that included PGC BD data identified five more loci [63]. In one of the most important studies on the subject, a genome-wide association study was conducted with 20,352 cases compared to 31,358 controls. A total of 822 sentinel variants were followed up independently in 9412 cases versus 137,760 controls. As a result, 30 loci (with 20 new ones) achieved significant genomic association evidence and contained genes coding for synaptic components (ANK3, RIMS1) and transporters, neurotransmitters and ion channels (SLC4A1, CACNA1C, $S C N 2 A, G R I N 2 A)$. Interestingly type I BD is genetically highly correlated with schizophrenia, while type II bipolar disorder correlates more with major depressive disorder [62,63]. In summary, the results of the broader genomic analysis on BD have revealed that these conditions have an extensive polygenic architecture, implicating in their etiology neurotransmitter and calcium channel functions, confirming that BD falls within a spectrum of highly related psychiatric disorders [55]. The detailed genetic dissection of the disorder, rationalized using a systems biology approach, could allow the identification of functional connections between the different molecular effectors identified, leading to the construction of a molecular network underlying the pathogenesis of the disease. This could also represent a valuable tool to guide, optimize, and personalize the therapeutic choice of molecular targets.

\section{Pharmacogenomics of Bipolar Spectrum Disorder}

The study of pharmacogenomics in the field of mental health is rapidly growing. Most data on genomics of bipolar spectrum disorders concentrate on the variability (response, side effects) of the pharmacological response when using atypical antipsychotics and/or antidepressants $[36,64]$. The genetic assets used in clinical settings are based mostly on the pharmacogenomic studies associating gene polymorphisms with treatment outcomes. In particular, genetic polymorphisms can affect pharmacodynamic and pharmacokinetic aspects of medications, thus influencing efficacy and susceptibility to side effects. 
With the increased accessibility of individual DNA chip analysis, WES (whole-exome sequencing,) and WGS (whole-genome sequencing) for diagnostic studies [65], pharmacogenomics is entering a phase of regular clinical use. The analysis of some key point mutations is actually required before specific drugs can be administered, in order to personalize the treatment according to the predicted efficacy or sensitivity to side effects [66]. Genetic variants to be analyzed for each class of drugs are selected according to available evidence-based medicine data and clinical validations, and several dedicated databases are available and freely accessible on the web today (e.g., pharmGKB [67], drugbank [68], genecards [69]).

Several factors can increase the possibility of a genetic diathesis in the treatment of bipolar spectrum disorders. Some meaningful SNPs are used in clinical settings to predict therapeutic response or potential toxicity. Polygenic determinants of drug effects have become more and more important in pharmacogenomics and are now used in clinical diagnostics to prevent adverse reactions to medications and to optimize therapy. Certain aspects of pharmacogenomic testing have entered the clinical routine. For example, FDA recommends testing for $H L A-B^{*} 1502$ when using carbamazepine. Carriers of this mutation are estimated to have a 10-fold higher risk for Stevens-Johnson syndrome when assuming the drug [70]. Today, the majority of tests available include both pharmacodynamic (PD) and pharmacokinetic (PK) genomic analytical panels.

\subsection{Pharmacogenomics of Pharmacodynamic Pathways}

Examples of genes implicated in the pharmacodynamics of neuropsychiatric drugs include COMT, DRD2 dopamine receptor, HTR2C and HTR2A serotonin receptors, and SLC6A4 serotonin transporter [71-74].

Serotonergic pathways have been the focus of most pharmacogenetic studies on clinical response to psychotropic drugs in BD patients. Alterations of these pathways have been implicated in bipolar disorders. The serotonin transporter SLC6A4 gene has been extensively investigated. 5-HTTLPR is a functional polymorphism of SLC6A4, with a short (s) and a long (1) allele variant that have been suggested to be related to stress and psychiatric disorders. There have been reports associating the (s) allele with poor response to serotonergic drugs in BD. On the other hand, genetic studies on the (l) allele and SSRI response have not been able to clearly demonstrate a functional association between gene expression and pharmacological effect. For example, rs25531, a SNP located in the same SLC6A4 region as 5-HTTLPR, although associated with increased transporter expression, does not affect the response to SSRIs $[75,76]$.

The HTR2A gene for 5HT-2A receptors (5HT2ARs) has been associated with antidepressant effect. Patients with specific polymorphisms of this gene (rs6313 and rs7997012) have been found to respond better to antidepressants. The same mutations have also been associated with an increased sensitivity of 5HT2ARs to serotonin [77,78]. 5HT2ARs hypersensitivity found in rs6313 and rs7997012 genetic mutations has been associated with the occurrence of pharmacologically induced dysphoric conditions in misdiagnosed bipolar spectrum disorders [15]. Several studies have shown an association between a good response to drugs that act on the serotonergic pathway in BD patients, and the rs6295 C/C genotype in the HTR1A gene [79-81]. The HTR2C gene for the 5HT-2C receptor has been shown to be associated with adverse drug reactions when using neuroleptic drugs. There is evidence indicating an association of specific polymorphisms like variant rs3813929 with a higher risk of extrapyramidal side effects. Another polymorphism, rs1414334, has been associated with higher risk of developing metabolic syndrome in subjects treated with olanzapine $[82,83]$.

Dopamine 2 receptors have been associated with antipsychotic effect and are coded by the highly polymorphic DRD2 gene, located on chromosome 11q22. An extensively studied variant is $-141 \mathrm{C}$ Ins/Del (rs1799732). When the Ins/Ins genotype is present, patients respond better to antipsychotic drugs than subjects carrying one or two copies of the Del allele. Subjects carrying the homozygous C allele with rs2514218 have been shown to respond better to antipsychotics than those homozygous for $\mathrm{T}$ allele, but they also present more side effects [84-86]. 
Little evidence is available on genes encoding for glutamate receptors. Research has been focused on the $G \beta 3$ gene, with studies reporting an association between a good response to drugs that act on the serotoninergic pathway in BD patients, and the T/T genotype in the rs5443 polymorphism [79,87].

Table 1 shows some of the most important pharmacodynamic mutations that can modify the pharmacotoxicological outcomes of drugs in bipolar disorder.

Table 1. SNPs relevant for the pharmacodynamics of drugs used for treatment of bipolar spectrum disorders.

\begin{tabular}{|c|c|c|c|c|c|c|}
\hline Gene & Protein & SNPs & Drugs & Results & $\begin{array}{l}\text { Level of } \\
\text { Evidence (1A } \\
\text { Strongest) }\end{array}$ & Ref. \\
\hline$A D C Y 1$ & Adenylate cyclase 1 & rs1521470 & lithium & $\begin{array}{l}\text { Patients with the AA genotype } \\
\text { and bipolar affective disorder } \\
\text { may have a decreased response } \\
\text { to lithium as compared to } \\
\text { patients with the AG or GG } \\
\text { genotypes. }\end{array}$ & 3 & [88] \\
\hline$A D C Y 2$ & adenylate cyclase 2 & $\begin{array}{l}\text { rs1544938 } \\
\text { rs4702484 }\end{array}$ & antipsychotics & $\begin{array}{l}\text { Patients with the CC genotype } \\
\text { may have increased response to } \\
\text { antipsychotics compared to } \\
\text { patients with the GG genotype. }\end{array}$ & 3 & [89] \\
\hline \multirow[t]{2}{*}{$A D R B 2$} & \multirow[t]{2}{*}{ Adrenoceptor beta 2} & \multirow[t]{2}{*}{$\begin{array}{l}\text { rs1042713 } \\
\text { rs8050896 }\end{array}$} & \multirow[t]{2}{*}{$\begin{array}{l}\text { risperidone } \\
\text { paliperidone }\end{array}$} & $\begin{array}{l}\text { Patients with the GG or AG } \\
\text { genotype may have increased } \\
\text { likelihood of sexual adverse } \\
\text { events when treated with } \\
\text { risperidone as compared to } \\
\text { patients with the AA genotype. }\end{array}$ & 3 & \multirow[t]{2}{*}[90,91]{} \\
\hline & & & & $\begin{array}{l}\text { Patients with the TT genotype } \\
\text { may have an increased } \\
\text { response to risperidone as } \\
\text { compared to patients with the } \\
\text { AA or AT genotypes. }\end{array}$ & 3 & \\
\hline AKT1 & $\begin{array}{c}\text { AKT } \\
\text { serine/threonine } \\
\text { kinase } 1\end{array}$ & rs2494732 & $\begin{array}{l}\text { risperidone } \\
\text { paliperidone }\end{array}$ & $\begin{array}{l}\text { Patients with the TT may have } \\
\text { an increased response to } \\
\text { risperidone as compared to } \\
\text { patients with the CC or CT } \\
\text { genotype. }\end{array}$ & 3 & {$[92]$} \\
\hline ASIC2 & $\begin{array}{l}\text { Acid sensing ion } \\
\text { channel subunit } 2\end{array}$ & rs11869731 & lithium & $\begin{array}{l}\text { Patients with the CC genotype } \\
\text { may have a better response to } \\
\text { lithium. }\end{array}$ & 3 & [94] \\
\hline \multirow[t]{2}{*}{$B D N F$} & \multirow[t]{2}{*}{$\begin{array}{l}\text { Brain derived } \\
\text { neurotrophic factor }\end{array}$} & \multirow[t]{2}{*}{$\begin{array}{c}\text { rs6265 } \\
\text { rs11030104 }\end{array}$} & \multirow[t]{2}{*}{$\begin{array}{l}\text { antipsychotics } \\
\text { antidepressants }\end{array}$} & $\begin{array}{l}\text { Patients with the AA genotype } \\
\text { and schizophrenia may show } \\
\text { less resistance to treatment } \\
\text { with antipsychotics as } \\
\text { compared to patients with the } \\
\text { AG or GG genotype. }\end{array}$ & 3 & \multirow[t]{2}{*}[25,75,95]{} \\
\hline & & & & $\begin{array}{l}\text { Patients with the CC genotype } \\
\text { and depressive disorder may } \\
\text { be more likely to respond to } \\
\text { paroxetine but less likely to } \\
\text { respond to citalopram or } \\
\text { antidepressants as compared to } \\
\text { patients with the CT or TT } \\
\text { genotype. }\end{array}$ & 3 & \\
\hline CACNG2 & $\begin{array}{c}\text { Calcium } \\
\text { voltage-gated } \\
\text { channel auxiliary } \\
\text { subunit gamma } 2\end{array}$ & $\begin{array}{l}\mathrm{rs} 2284018 \\
\mathrm{rs} 2284017\end{array}$ & lithium & $\begin{array}{l}\text { Patients with the CC or CT } \\
\text { genotype may be more likely to } \\
\text { respond to lithium. }\end{array}$ & 3 & {$[96,97]$} \\
\hline
\end{tabular}


Table 1. Cont.

\begin{tabular}{|c|c|c|c|c|c|c|}
\hline Gene & Protein & SNPs & Drugs & Results & $\begin{array}{c}\text { Level of } \\
\text { Evidence (1A } \\
\text { Strongest) }\end{array}$ & Ref. \\
\hline CCL2 & $\begin{array}{c}\text { C-C motif } \\
\text { chemokine ligand } 2\end{array}$ & rs4586 & $\begin{array}{l}\text { risperidone } \\
\text { paliperidone }\end{array}$ & $\begin{array}{l}\text { Patients with the GG genotype } \\
\text { and schizophrenia may have a } \\
\text { poorer response when treated } \\
\text { with risperidone as compared } \\
\text { to patients with the AA or AG } \\
\text { genotype. }\end{array}$ & 3 & [98] \\
\hline CNR1 & $\begin{array}{l}\text { Cannabinoid } \\
\text { receptor } 1\end{array}$ & $\begin{array}{l}\text { rs1049353 } \\
\text { rs806378 }\end{array}$ & $\begin{array}{l}\text { aripiprazole } \\
\text { clozapine } \\
\text { haloperidol } \\
\text { olanzapine } \\
\text { quetiapine } \\
\text { risperidone }\end{array}$ & $\begin{array}{l}\text { Patients with the CC genotype } \\
\text { and psychotic disorders may } \\
\text { have an increased likelihood of } \\
\text { weight gain as compared to } \\
\text { patients with the CT and CC } \\
\text { genotypes. }\end{array}$ & 3 & [99] \\
\hline \multirow{2}{*}{ COMT } & \multirow{2}{*}{$\begin{array}{l}\text { catechol-O- } \\
\text { methyltransferase }\end{array}$} & \multirow{2}{*}{$\begin{array}{c}\text { rs } 4818 \\
\text { rs } 4680 \\
\text { rs13306278 }\end{array}$} & \multirow{2}{*}{$\begin{array}{l}\text { antipsychotics } \\
\text { SSRI }\end{array}$} & $\begin{array}{l}\text { Patients with the AA genotype } \\
\text { may have increased blood } \\
\text { pressure when treated with } \\
\text { antipsychotics as compared to } \\
\text { patients with the GG genotype. }\end{array}$ & 3 & \multirow{2}{*}[100,101]{} \\
\hline & & & & $\begin{array}{l}\text { Patients with the CC genotype } \\
\text { may have increased likelihood } \\
\text { of remission when treated with } \\
\text { Selective serotonin reuptake } \\
\text { inhibitors compared to patients } \\
\text { with the TT or CT genotype. }\end{array}$ & $2 \mathrm{~B}$ & \\
\hline CPS1 & $\begin{array}{l}\text { Carbamoyl-phosphate } \\
\text { synthase } 1\end{array}$ & $\begin{array}{l}\text { complete } \\
\text { gene } \\
\text { sequencing }\end{array}$ & $\begin{array}{c}\text { valproic acid } \\
\text { Testing } \\
\text { suggested by } \\
\text { FDA and PMDA }\end{array}$ & $\begin{array}{l}\text { Valproic acid is contraindicated } \\
\text { in patients with known urea } \\
\text { cycle disorders (UCDs), due to } \\
\text { a risk for severe } \\
\text { hyperammonemia. UCDs } \\
\text { result from mutations in one of } \\
\text { several genes, such as } \\
\text { carbamoyl-phosphate } \\
\text { synthetase } 1 \text { (CPS1) deficiency. }\end{array}$ & none & [102] \\
\hline DRD1 & $\begin{array}{l}\text { Dopamine receptor } \\
\text { D1 }\end{array}$ & rs 4532 & lithium & $\begin{array}{l}\text { Patients with the TT genotype } \\
\text { may have an increased } \\
\text { response to lithium as } \\
\text { compared to patients with the } \\
\text { CC genotype. }\end{array}$ & 4 & [103] \\
\hline$D R D 2$ & $\begin{array}{l}\text { Dopamine receptor } \\
\text { D2 }\end{array}$ & $\begin{array}{l}\text { rs1800497 } \\
\text { rs1799978 }\end{array}$ & antipsychotics & $\begin{array}{l}\text { Patients with the AA genotype } \\
\text { may have increased risk of side } \\
\text { effects including } \\
\text { hyperprolactinemia and weight } \\
\text { gain, but decreased risk of } \\
\text { tardive dyskinesia, during } \\
\text { treatment with antipsychotic } \\
\text { drugs as compared to patients } \\
\text { with the AG or GG genotype. }\end{array}$ & $2 B$ & $\begin{array}{c}{[93,104,} \\
105]\end{array}$ \\
\hline$D R D 3$ & $\begin{array}{c}\text { Dopamine receptor } \\
\text { D3 }\end{array}$ & rs6280 & quetiapine & $\begin{array}{l}\text { People with TT genotype may } \\
\text { have increased clearance of } \\
\text { quetiapine compared with } \\
\text { people with genotypes CC or } \\
\text { CT. }\end{array}$ & 3 & {$[106,107]$} \\
\hline$E P M 2 A$ & $\begin{array}{l}\text { EPM2A, laforin } \\
\text { glucan phosphatase }\end{array}$ & rs1415744 & $\begin{array}{l}\text { chlorpromazine } \\
\text { clozapine } \\
\text { haloperidol } \\
\text { olanzapine } \\
\text { quetiapine } \\
\text { risperidone }\end{array}$ & $\begin{array}{l}\text { Patients with the CC genotype } \\
\text { and schizophrenia may have } \\
\text { increased response to } \\
\text { chlorpromazine, clozapine, } \\
\text { haloperidol, olanzapine, } \\
\text { quetiapine, and risperidone } \\
\text { compared to patients with the } \\
\text { CT and TT genotypes. }\end{array}$ & 3 & [108] \\
\hline
\end{tabular}


Table 1. Cont.

\begin{tabular}{|c|c|c|c|c|c|c|}
\hline Gene & Protein & SNPs & Drugs & Results & $\begin{array}{c}\text { Level of } \\
\text { Evidence (1A } \\
\text { Strongest) }\end{array}$ & Ref. \\
\hline$F A A H$ & $\begin{array}{l}\text { Fatty acid amide } \\
\text { hydrolase }\end{array}$ & rs324420 & $\begin{array}{l}\text { aripiprazole } \\
\text { clozapine } \\
\text { haloperidol } \\
\text { olanzapine } \\
\text { quetiapine } \\
\text { risperidone }\end{array}$ & $\begin{array}{l}\text { Patients with the AA genotype } \\
\text { and psychotic disorders who } \\
\text { are treated with aripiprazole, } \\
\text { clozapine, haloperidol, } \\
\text { olanzapine, quetiapine, or } \\
\text { risperidone may have an } \\
\text { increased likelihood of weight } \\
\text { gain of more than } 7 \% \text { of } \\
\text { baseline body weight as } \\
\text { compared to patients with the } \\
\text { CC genotype. }\end{array}$ & 3 & [109-112] \\
\hline FAM177A1 & $\begin{array}{c}\text { Family with } \\
\text { sequence similarity } \\
177 \text { member A1 }\end{array}$ & rs79403677 & lithium & $\begin{array}{l}\text { Patients with the GG genotype } \\
\text { and bipolar affective disorder } \\
\text { may have an increased } \\
\text { response to lithium as } \\
\text { compared to patients with the } \\
\text { GT or TT genotypes. }\end{array}$ & 3 & [88] \\
\hline FAM178B & $\begin{array}{l}\text { Family with } \\
\text { sequence similarity } \\
178 \text { member B }\end{array}$ & rs6728642 & lithium & $\begin{array}{l}\text { Patients with the AA genotype } \\
\text { and bipolar affective disorder } \\
\text { may have a decreased response } \\
\text { to lithium as compared to } \\
\text { patients with the AG or GG } \\
\text { genotypes. }\end{array}$ & 3 & [88] \\
\hline FКВР5 & $\begin{array}{l}\text { FKBP prolyl } \\
\text { isomerase } 5\end{array}$ & rs1360780 & $\begin{array}{l}\text { clomipramine } \\
\text { lithium } \\
\text { paroxetine } \\
\text { venlafaxine }\end{array}$ & $\begin{array}{l}\text { Patients with the CC genotype } \\
\text { may (1) have decreased } \\
\text { response to antidepressants (2) } \\
\text { have decreased, but not absent, } \\
\text { risk for suicide ideation with } \\
\text { paroxetine, venlafaxine, } \\
\text { clomipramine, and lithium, as } \\
\text { compared to patients with the } \\
\text { CT or TT genotype. }\end{array}$ & $2 \mathrm{~B}$ & [103] \\
\hline GADL1 & $\begin{array}{c}\text { glutamate } \\
\text { decarboxylase like } 1\end{array}$ & rs17026688 & lithium & $\begin{array}{l}\text { Allele } \mathrm{T} \text { is associated with } \\
\text { increased response to lithium } \\
\text { when treated with lithium in } \\
\text { people with bipolar disorder as } \\
\text { compared to allele C. }\end{array}$ & none & {$[90,114]$} \\
\hline GNB3 & $\begin{array}{l}\text { G protein subunit } \\
\text { beta } 3\end{array}$ & rs5443 & $\begin{array}{l}\text { risperidone } \\
\text { paliperidone } \\
\text { olanzapine }\end{array}$ & $\begin{array}{l}\text { Patients with the CC genotype } \\
\text { and schizophrenia who are } \\
\text { treated with olanzapine may } \\
\text { have a decreased, but not } \\
\text { absent, risk of weight gain as } \\
\text { compared to patients with the } \\
\text { CT or TT genotype. }\end{array}$ & 3 & [115] \\
\hline GRAMD1B & $\begin{array}{l}\text { GRAM domain } \\
\text { containing 1B }\end{array}$ & rs61123830 & lithium & $\begin{array}{l}\text { Patients with the AA genotype } \\
\text { and bipolar affective disorder } \\
\text { may have a decreased response } \\
\text { to lithium as compared to } \\
\text { patients with the AG or GG } \\
\text { genotypes. }\end{array}$ & 3 & [88] \\
\hline GRID2 & $\begin{array}{c}\text { Glutamate } \\
\text { ionotropic receptor } \\
\text { delta type subunit } 2\end{array}$ & rs1875705 & $\begin{array}{l}\text { risperidone } \\
\text { paliperidone }\end{array}$ & $\begin{array}{l}\text { Patients with the GG genotype } \\
\text { may have an increased } \\
\text { response to risperidone as } \\
\text { compared to patients with the } \\
\text { AA and AG genotypes. }\end{array}$ & 3 & [116] \\
\hline
\end{tabular}


Table 1. Cont.




Table 1. Cont.

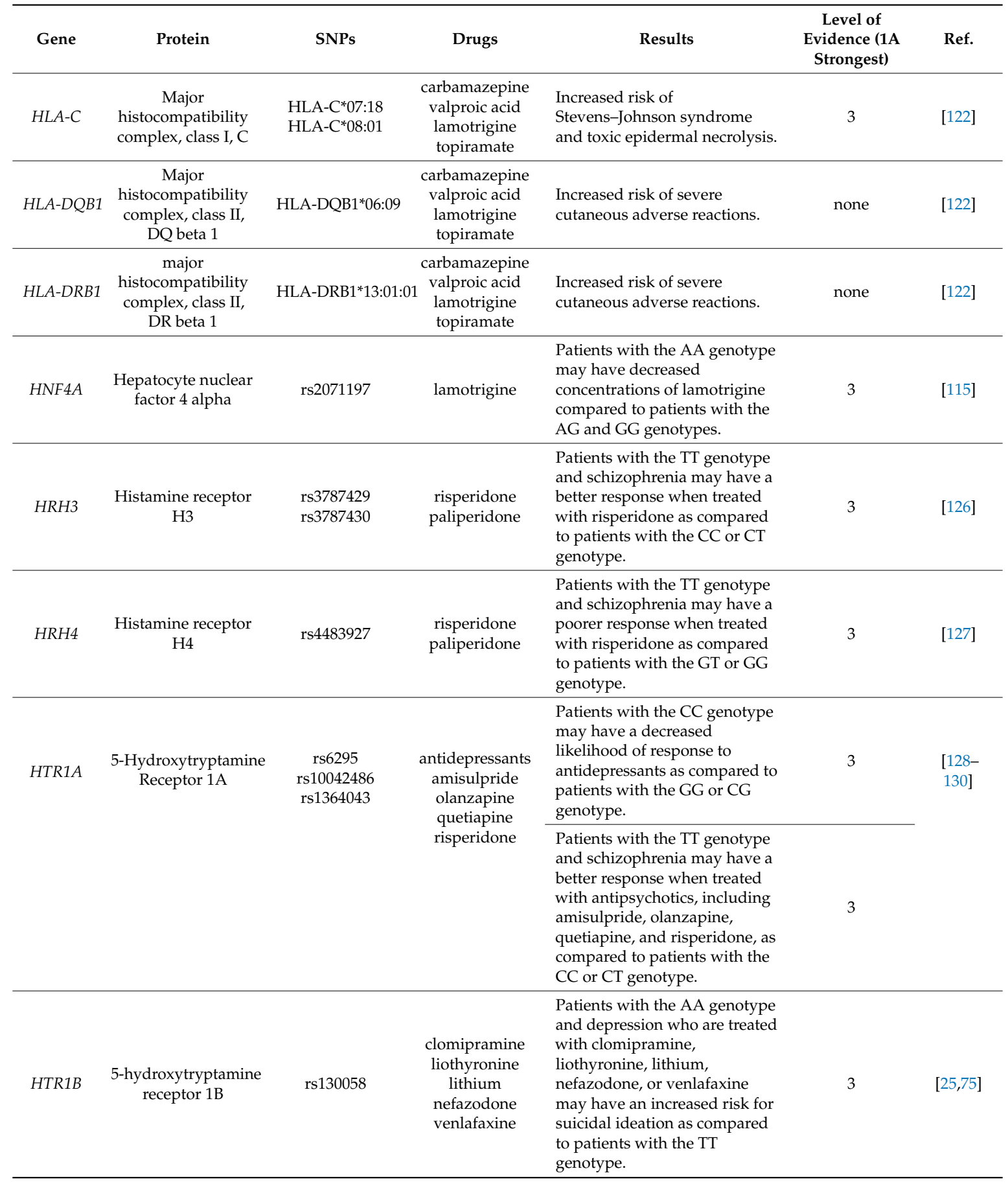


Table 1. Cont.

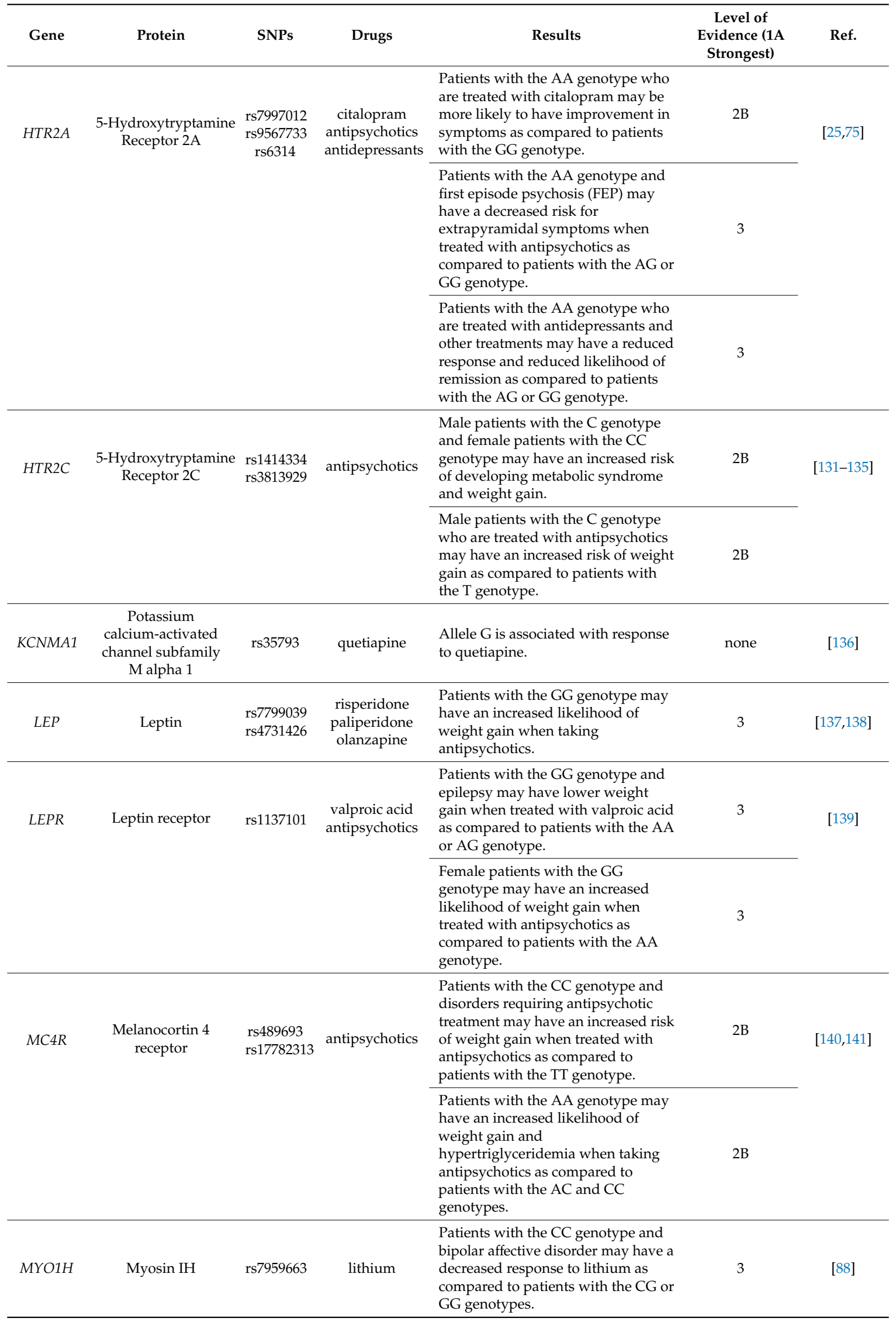


Table 1. Cont.

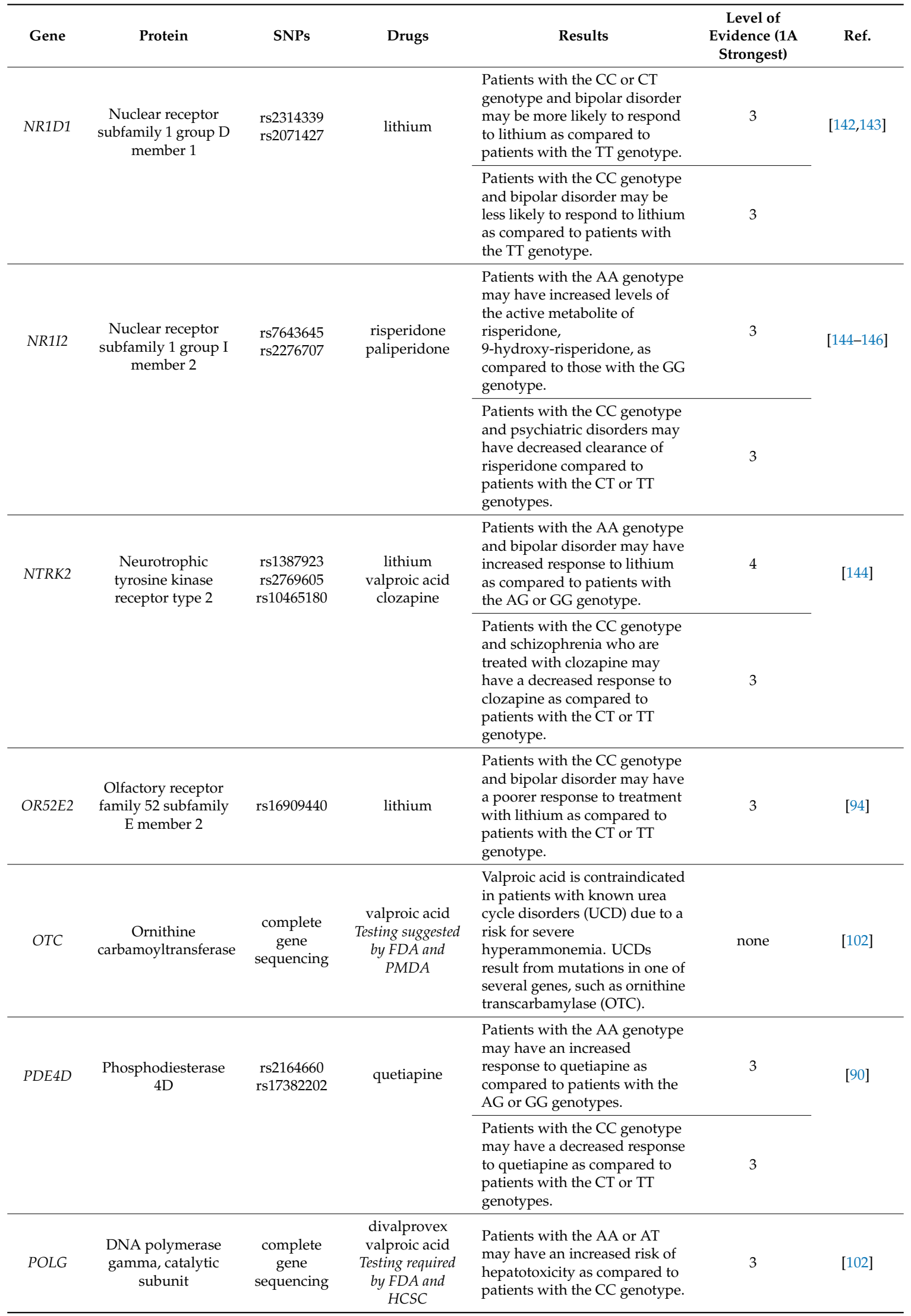


Table 1. Cont.

\begin{tabular}{|c|c|c|c|c|c|c|}
\hline Gene & Protein & SNPs & Drugs & Results & $\begin{array}{l}\text { Level of } \\
\text { Evidence (1A } \\
\text { Strongest) }\end{array}$ & Ref. \\
\hline PPA2 & $\begin{array}{l}\text { Pyrophosphatase } \\
\quad \text { (inorganic) } 2\end{array}$ & rs2636719 & $\begin{array}{l}\text { risperidone } \\
\text { paliperidone }\end{array}$ & $\begin{array}{l}\text { Patients with the CC genotype } \\
\text { may have an increased } \\
\text { response to risperidone as } \\
\text { compared to patients with the } \\
\text { AA or AC genotypes. }\end{array}$ & 3 & [90] \\
\hline \multirow[t]{2}{*}{ SCN1A } & \multirow[t]{2}{*}{$\begin{array}{l}\text { Sodium } \\
\text { voltage-gated } \\
\text { channel alpha } \\
\text { subunit } 1\end{array}$} & \multirow[t]{2}{*}{$\begin{array}{l}\text { rs2298771 } \\
\text { rs3812718 }\end{array}$} & \multirow{2}{*}{$\begin{array}{l}\text { carbamazepine } \\
\text { phenytoin } \\
\text { valproic acid } \\
\text { lamotrigine } \\
\text { topiramate } \\
\text { oxcarbazepine }\end{array}$} & $\begin{array}{l}\text { Patients with the CC genotype } \\
\text { who are treated with mono or } \\
\text { combination antiepileptic } \\
\text { therapy may have an improved } \\
\text { response. }\end{array}$ & 3 & \multirow[t]{2}{*}{ [150-152] } \\
\hline & & & & $\begin{array}{l}\text { Patients with the CC genotype } \\
\text { who are treated with phenytoin } \\
\text { may require a lower dose. }\end{array}$ & $2 B$ & \\
\hline$S C N 2 A$ & $\begin{array}{l}\text { Sodium } \\
\text { voltage-gated } \\
\text { channel alpha } \\
\text { subunit } 2\end{array}$ & $\begin{array}{l}\text { rs17183814 } \\
\text { rs2304016 }\end{array}$ & $\begin{array}{l}\text { carbamazepine } \\
\text { valproic acid } \\
\text { lamotrigine }\end{array}$ & $\begin{array}{l}\text { Patients with the GG genotype } \\
\text { may be more likely to respond. }\end{array}$ & 3 & {$[153,154]$} \\
\hline$S L C 22 A 8$ & $\begin{array}{l}\text { Solute carrier family } \\
\qquad 22 \text { member } 8\end{array}$ & rs2276299 & $\begin{array}{l}\text { risperidone } \\
\text { paliperidone }\end{array}$ & $\begin{array}{l}\text { Allele } \mathrm{A} \text { is not associated with } \\
\text { risk of hyperprolactinemia } \\
\text { when treated with risperidone } \\
\text { in children. }\end{array}$ & none & [157] \\
\hline SLC6A4 & $\begin{array}{l}\text { Solute carrier family } \\
\qquad 6 \text { member } 4\end{array}$ & $\begin{array}{l}\text { SLC6A4 } \\
\text { HTTLPR } \\
\text { long form (L } \\
\text { allele) } \\
\text { SLC6A4 } \\
\text { HTTLPR } \\
\text { short form (S } \\
\text { allele) }\end{array}$ & antidepressants & $\begin{array}{l}\text { HTTLPR short form (S } \\
\text { allele)/HTTLPR long form (L } \\
\text { allele) + HTTLPR short form (S } \\
\text { allele)/HTTLPR short form (S } \\
\text { allele) is associated with } \\
\text { non-response when treated } \\
\text { with antidepressants in people } \\
\text { with mood disorders as } \\
\text { compared to SLC6A4 HTTLPR } \\
\text { long form (L allele)/HTTLPR } \\
\text { long form (L allele). }\end{array}$ & $2 \mathrm{~B}, 3$ & {$[75,93,100]$} \\
\hline TAAR6 & $\begin{array}{l}\text { Trace amine } \\
\text { associated receptor } \\
6\end{array}$ & rs4305746 & aripiprazole & $\begin{array}{l}\text { Patients with the AA genotype } \\
\text { may have faster improvement } \\
\text { in brief psychiatric rating scale } \\
\text { (BPRS) scores when treated } \\
\text { with aripiprazole as compared } \\
\text { to patients with the GG } \\
\text { genotype. }\end{array}$ & 3 & [158] \\
\hline
\end{tabular}


Table 1. Cont.

\begin{tabular}{|c|c|c|c|c|c|c|}
\hline Gene & Protein & SNPs & Drugs & Results & $\begin{array}{l}\text { Level of } \\
\text { Evidence (1A } \\
\text { Strongest) }\end{array}$ & Ref. \\
\hline ТPH1 & $\begin{array}{c}\text { Tryptophan } \\
\text { hydroxylase } 1\end{array}$ & rs1799913 & lithium & $\begin{array}{l}\text { Genotype TT is associated with } \\
\text { decreased response to lithium } \\
\text { in people with bipolar disorder. }\end{array}$ & none & [159] \\
\hline ТPH2 & $\begin{array}{c}\text { Tryptophan } \\
\text { hydroxylase } 2\end{array}$ & $\begin{array}{l}\text { rs1487278 } \\
\text { rs2171363 } \\
\text { rs17110747 }\end{array}$ & quetiapine & $\begin{array}{l}\text { Patients with the CC or CT } \\
\text { genotype may respond better } \\
\text { to antidepressant treatments as } \\
\text { compared to patients with the } \\
\text { TT genotype. }\end{array}$ & 3 & [160] \\
\hline TYMS & $\begin{array}{l}\text { Thymidylate } \\
\text { synthetase }\end{array}$ & rs3786362 & $\begin{array}{l}\text { risperidone } \\
\text { paliperidone }\end{array}$ & $\begin{array}{l}\text { Allele } \mathrm{A} \text { is associated with } \\
\text { increased risk of } \\
\text { hyperprolactinemia when } \\
\text { treated with risperidone. }\end{array}$ & none & [114] \\
\hline
\end{tabular}

\subsection{Pharmacogenomics of Pharmacokinetic Pathways}

CYP enzyme polymorphisms (cytochrome P450) may result in increased or decreased enzymatic activity. Such variations can thus determine a wide variety of drug metabolic patterns that, depending on the resulting metabolic activity, characterize the subject as a normal metabolizer, ultra-rapid metabolizer, intermediate metabolizer, or poor metabolizer. Poor metabolizers are subjects that have poor to no enzymatic activity, usually associated with having two copies of non-functioning alleles. Medications targeted by these enzymes are not metabolized effectively, thus increasing the risk of adverse drug reactions. In the case of pro-drugs, this condition can result in therapeutic failure, since the medication will not be transformed into the active form. Intermediate metabolizers have a slight functional impairment of drug metabolic activity due to at least one non-functioning allele. Normal metabolizers have a regular drug metabolic activity, while ultra-rapid metabolizers have enhanced enzyme activity that leads to an increased ability to metabolize drugs, decreasing the effectiveness of drugs, or increasing the risk of adverse drug reactions of prodrugs. For reference, the Clinical Pharmacogenetics Implementation Consortium (CPIC) published a review on pharmacogenomics nomenclature [161,162].

The drug metabolism (phase I) of psychiatric medications involves CYP 1 to three families, including CYP1A2, CYP2B6, CYP3A4/5, CYP2C9, CYP2C19, and CYP2D6. These CYP enzymes can be analyzed to personalize drug prescription and administration [163].

The FDA labeling (US Food and Drug Administration) of about 200 drugs specify their pharmacogenomic characterization. Neuropsychiatric medications represent one fourth of all these drugs. With pharmacogenomic information on the type of metabolizer, it is possible to choose the most effective drug for a patient, and identify the dose range and the administration strategy.

Table 2 shows some of the most important pharmacokinetic mutations that can modify the pharmacotoxicological outcome of the drugs in bipolar disorder. 
Table 2. SNPs relevant for pharmacokinetics of drugs used for treatment of bipolar spectrum disorders.

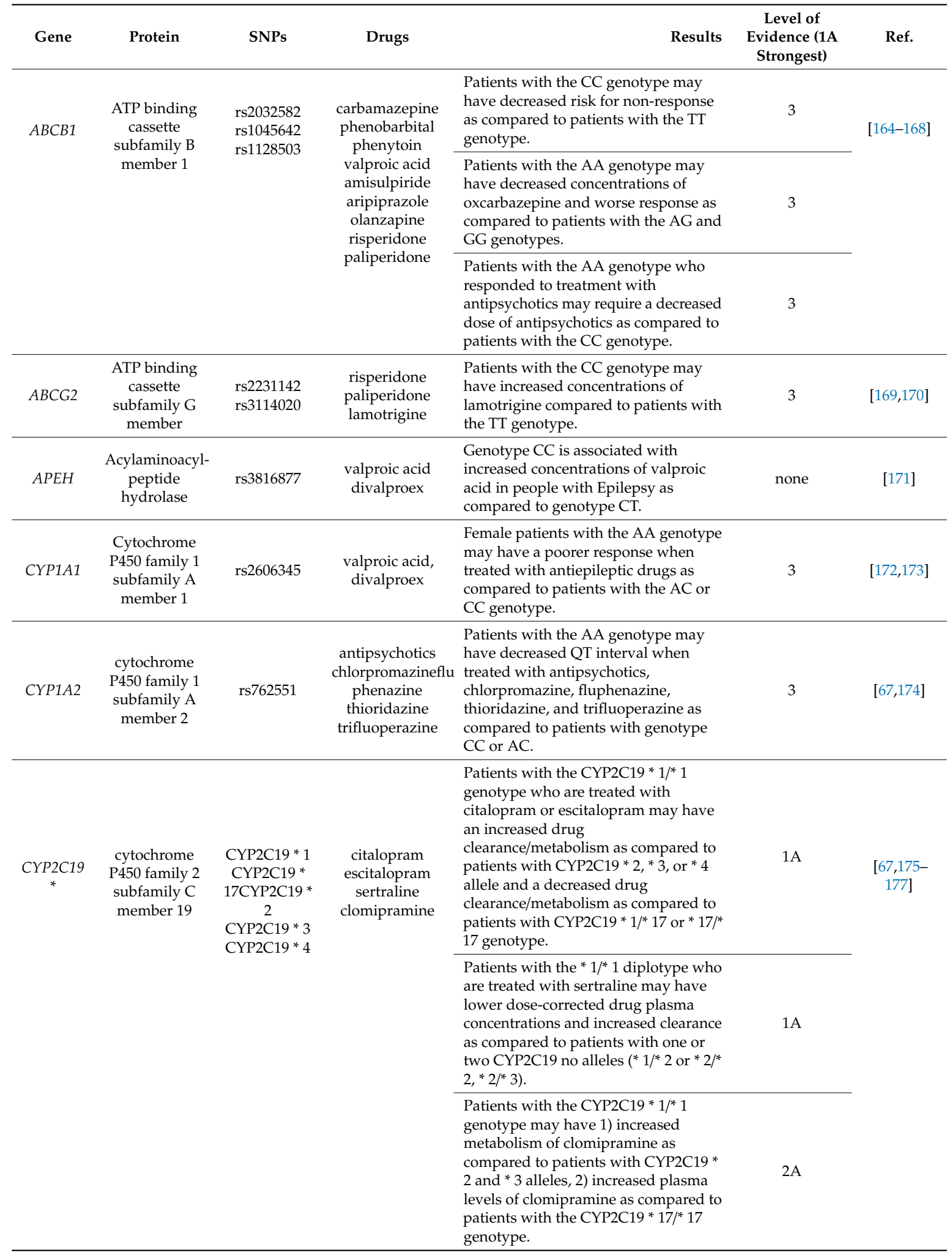


Table 2. Cont

\begin{tabular}{|c|c|c|c|c|c|c|}
\hline Gene & Protein & SNPs & Drugs & Results & $\begin{array}{c}\text { Level of } \\
\text { Evidence (1A } \\
\text { Strongest) }\end{array}$ & Ref. \\
\hline СУР2C9 & $\begin{array}{c}\text { cytochrome } \\
\text { P450 family } 2 \\
\text { subfamily C } \\
\text { member } 9\end{array}$ & $\begin{array}{l}\text { СУР2C9*1 } \\
\text { СYР2C9*2 } \\
\text { СYР2C9*3 }\end{array}$ & $\begin{array}{l}\text { valproic acid } \\
\text { divalproex } \\
\text { olanzapine }\end{array}$ & $\begin{array}{l}\text { Patients with the }{ }^{*} 1 /^{*} 1 \text { genotype and } \\
\text { bipolar disorder and other psychotic } \\
\text { disorders may have increased dose of } \\
\text { valproic acid compared to patients } \\
\text { with the }{ }^{*} 1{ }^{*} 2 \text { and } * 1 / * 3 \text { genotypes. }\end{array}$ & 3 & $\begin{array}{c}{[67,178} \\
179]\end{array}$ \\
\hline \multirow[t]{5}{*}{$\begin{array}{c}\text { CYP2D } 6 \\
*\end{array}$} & \multirow[t]{5}{*}{$\begin{array}{l}\text { cytochrome } \\
\text { P450 family } 2 \\
\text { subfamily D } \\
\text { member } 6\end{array}$} & \multirow{5}{*}{$\begin{array}{c}\text { CYP2D6*1 } \\
\text { CYP2D6 *10 } \\
\text { CYP2D6* } \\
\text { 1xNCYP2D6 } \\
* 2 \\
\text { CYP2D6* } \\
\text { 2xNCYP2D6 } \\
* 3 \\
\text { CYP2D6 *4 } \\
\text { CYP2D6*5 } \\
\text { CYP2D6*6 } \\
\text { rs3892097 }\end{array}$} & \multirow{5}{*}{$\begin{array}{l}\text { paroxetine } \\
\text { fluvoxamine } \\
\text { risperidone } \\
\text { clomipramine } \\
\text { quetiapine } \\
\text { valproic acid } \\
\text { divalproex } \\
\text { aripiprazole } \\
\text { Testing suggested } \\
\text { by FDA, EMA, } \\
\text { DPWG and } \\
\text { HCSC for } \\
\text { aripiprazole, } \\
\text { risperidone }\end{array}$} & $\begin{array}{l}\text { Patients with the CYP2D } *^{*} 1 /^{*} 1 \\
\text { genotype who are treated with } \\
\text { paroxetine may have }(1) \text { a decreased } \\
\text { clearance of paroxetine as compared to } \\
\text { patients with more than two functional } \\
\text { CYP2D6 alleles }(* 1 \times N, * 2 \times N) \text { and }(2) \\
\text { an increased clearance of paroxetine as } \\
\text { compared to patients with two } \\
\text { non-functional CYP2D6 alleles }(* 3, * 4, \\
* 5, * 6) \text { or } * 10 * 10 \text { genotype. }\end{array}$ & $1 \mathrm{~A}$ & \multirow[t]{5}{*}{$\begin{array}{c}{[67,180-} \\
183]\end{array}$} \\
\hline & & & & $\begin{array}{l}\text { Patients with the CYP2D }{ }^{*} 1 / * 1 \\
\text { genotype who are treated with } \\
\text { fluvoxamine may have } 1 \text { ) decreased } \\
\text { steady-state plasma } \\
\text { concentration-to-dose }(\mathrm{C} / \mathrm{D}) \text { ratio as } \\
\text { compared to patients with the } * 1 /{ }^{*} 5,{ }^{*} \\
1 / * 10, * 5 / * 10, * 10 / * 10 \text { genotype, } 2) \\
\text { decreased plasma concentrations, } 3 \text { ) } \\
\text { decreased risk of developing } \\
\text { gastrointestinal side effects as } \\
\text { compared to patients with the } 5 / * 10, * \\
10 / * 10 \text { genotype, and } 4 \text { ) decreased } \\
\text { AUC, Cmax and half-life time of } \\
\text { fluvoxamine as compared to patients } \\
\text { with two non-functional CYP2D6 } \\
\text { alleles (poor metabolizer phenotypes). }\end{array}$ & $1 \mathrm{~A}$ & \\
\hline & & & & $\begin{array}{l}\text { Patients with the } * 1 \text { allele may have } \\
\text { increased metabolism/clearance of } \\
\text { risperidone as compared to patients } \\
\text { with two reduced function alleles }(* \\
10) \text {, one reduced function and one } \\
\text { non-functional }(* 4, * 5 \text {, or } * 14) \text { allele, } \\
\text { or two non-functional alleles. }\end{array}$ & $2 \mathrm{~A}$ & \\
\hline & & & & $\begin{array}{l}\text { Patients with the CC genotype } \\
(\text { CYP2D6*1/* } 1) \text { treated with tricyclic } \\
\text { antidepressants }(1) \text { may have a } \\
\text { decreased likelihood of switching } \\
\text { treatment indicating a reduced risk of } \\
\text { side effects }(2) \text { may require an } \\
\text { increased dose of drug as compared to } \\
\text { patients with the TT genotype } \\
(\text { CYP2D6*4/* } 4 \text {. }\end{array}$ & $1 \mathrm{~A}$ & \\
\hline & & & & $\begin{array}{l}\text { Patients with the CYP2D6 } * 1 /{ }^{*} 1 \\
\text { genotype treated with clomipramine } \\
\text { may have (1) a decreased, but not } \\
\text { absent, risk for side effects as } \\
\text { compared to patients with the CYP2D6 } \\
{ }^{*} 4 \text { allele, (2) increased plasma } \\
\text { concentration of clomipramine and } \\
\text { desmethyl clomipramine as compared } \\
\text { to patients with a duplication of a } \\
\text { functional CYP2D6 gene, (3) decreased } \\
\text { plasma concentration of clomipramine } \\
\text { and desmethyl clomipramine as } \\
\text { compared to patients with two } \\
\text { non-functional CYP2D6 alleles. }\end{array}$ & $1 \mathrm{~A}$ & \\
\hline
\end{tabular}


Table 2. Cont.

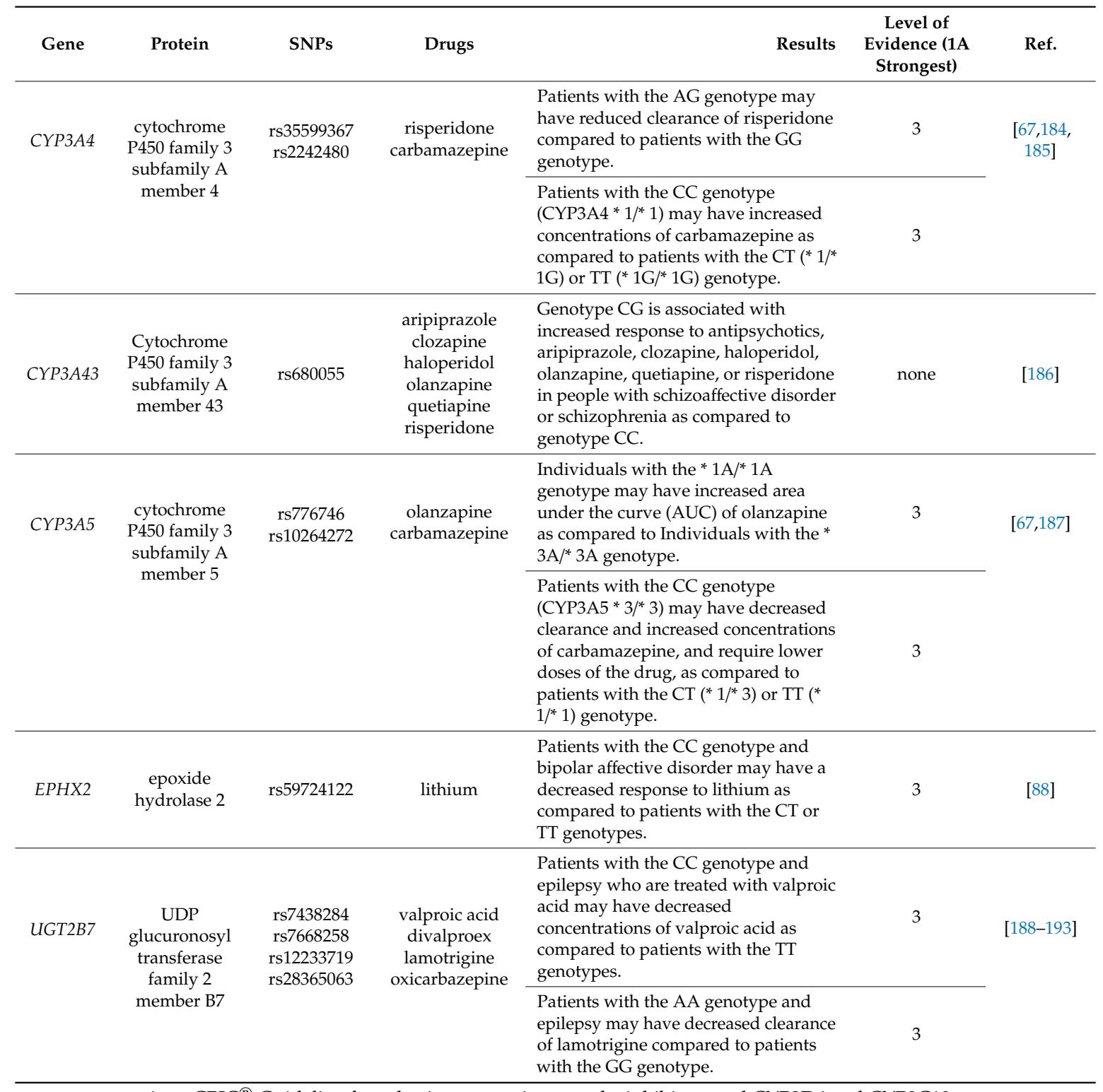

${ }^{*}$ see CPIC ${ }^{\circledR}$ Guideline for selective serotonin reuptake inhibitors and CYP2D6 and CYP2C19.

\section{Conclusions}

Bipolar spectrum disorder diagnosis is usually not based on the identification of pathogenetic mechanism, but on symptoms and signs, while the identification and association of traditional biological markers with bipolar disorder is still under investigation. The advent of genomics has allowed the identification of genetic assets associated with bipolar spectrum disorders, providing the basis for the identification of genetic risk factors and the definition of personalized pharmacotoxicological profiles. These can guide the initial therapeutic choice, or suggest corrections according to the individual's biological networks implicated in the disease pathways or in the relevant pharmacological aspects.

Even before they are diagnosed with a bipolar condition, patients usually claim a depressive symptomatology of some degree. Using the patient's molecular information can be helpful for the initial therapeutic orientation when a decision needs to be made on whether to use serotonergic antidepressants, given that mutations in their $H T R 2 A$ gene would suggest a risk of manic state induction.

Once the bipolar condition is diagnosed, pharmacogenomic information can be used to guide the choice of the class of drugs to be used. In particular, the analysis of pharmacodynamically relevant 
SNPs can support the identification of the type of drugs with most chance of being effective and/or least likelihood of causing side effects. This information should be combined with a complete family history and medical information, as well as regular clinical risk factor profiling for bipolar disorder.

When the type of drug class to be used has been identified, pharmacogenomic information can help to drive the choice of the best molecule according to the individual pharmacokinetic asset, and at the same time indicate the dose and the therapeutic strategy that should be used to optimize effectiveness and minimize the risks of side effects.

A proposed algorithm is shown in Figure 2.

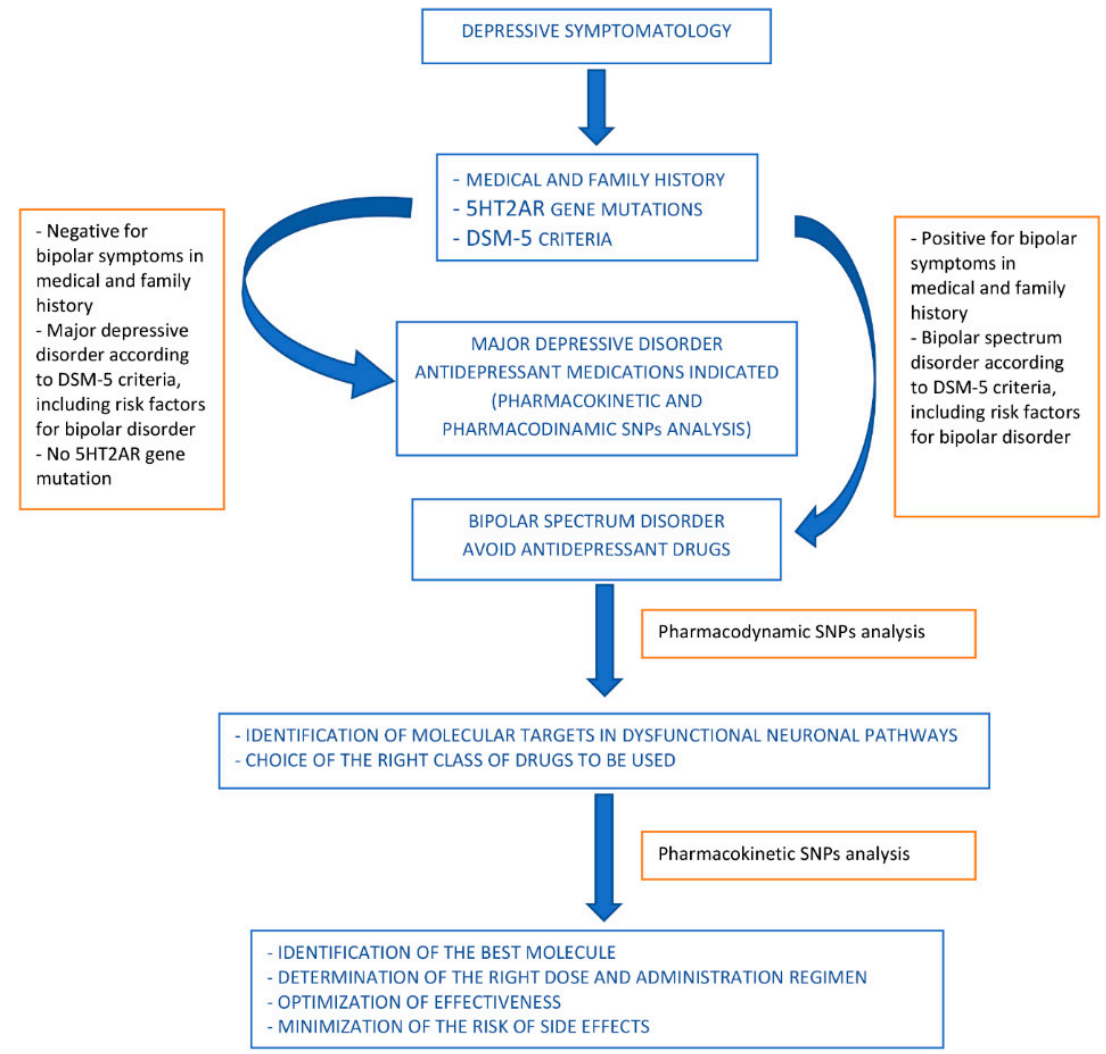

Figure 2. Proposed algorithm for drug use orientation in pharmacological treatment of bipolar spectrum disorders.

In summary, the genomic knowledge available today can support a personalized medicine approach to bipolar disorders, suggesting the most suitable pharmacological therapy for each patient. Together with the basic clinical information, a pharmacogenomic analysis should always be recommended to verify how one or more drugs might effectively act in a given subject, foreseeing the efficacy profile and safety of each drug, in order to increase therapeutic success and decrease unwanted adverse effects. Although more evidence is required before genomic data can be fully used to assist the clinician with a molecular diagnosis, when dealing with bipolar spectrum disorders, pharmacogenomics can provide orientation towards a safer use of drugs, particularly antidepressant drugs, based on the polymorphisms on the HTR2A gene. Once a bipolar disorder is diagnosed, drugs can be chosen based on the molecular targets identified by the pharmacodynamic SNPs, optimizing the doses and the pharmacological combinations based on the pharmacokinetic SNPs.

Funding: This research received no external funding.

Conflicts of Interest: The founding sponsors had no role in the design of the study; in the collection, analyses, or interpretation of data; in the writing of the manuscript, and in the decision to publish the results. 


\section{References}

1. Bobo, W.V. The diagnosis and management of bipolar I and II disorders: Clinical practice update. Mayo Clin. Proc. 2017, 92, 1532-1551. [CrossRef]

2. Ghaemi, S.N.; Sachs, G.S.; Chiou, A.M.; Pandurangi, A.K.; Goodwin, F.K. Is bipolar disorder still underdiagnosed? Are antidepressants overutilized? J. Affect. Disord. 1999, 52, 135-144. [CrossRef]

3. Ghaemi, S.N.; Hsu, D.J.; Soldani, F.; Goodwin, F.K. Antidepressants in bipolar disorder: The case for caution. Bipolar Disord. 2003, 5, 421-433. [CrossRef]

4. Grande, I.; Berk, M.; Birmaher, B.; Vieta, E. Bipolar disorder. Lancet 2016, 387, 1561-1572. [CrossRef]

5. Yatham, L.N.; Kennedy, S.H.; Parikh, S.V.; Schaffer, A.; Bond, D.J.; Frey, B.N.; Sharma, V.; Goldstein, B.I.; Rej, S.; Beaulieu, S.; et al. Canadian Network for Mood and Anxiety Treatments (CANMAT) and International Society for Bipolar Disorders (ISBD) 2018 guidelines for the management of patients with bipolar disorder. Bipolar Disord. 2018, 20, 97-170. [CrossRef]

6. Benazzi, F. Bipolar disorder-Focus on bipolar II disorder and mixed depression. Lancet 2018, 369, $935-945$. [CrossRef]

7. Phillips, M.L.; Kupfer, D.J. Bipolar disorder diagnosis: Challenges and future directions. Lancet 2013, 381, 1663-1671. [CrossRef]

8. Scott, J.; Leboyer, M. Consequences of delayed diagnosis of bipolar disorders. Encephale 2011, 37, S173-S175. [CrossRef]

9. Edvardsen, J.; Torgersen, S.; Røysamb, E.; Lygren, S.; Skre, I.; Onstad, S.; Oien, P.A. Heritability of bipolar spectrum disorders. Unity or heterogeneity? J. Affect Disord. 2008, 106, 229-240. [CrossRef]

10. Angst, J. The bipolar spectrum. Br. J. Psychiatry 2007, 190, 189-191. [CrossRef]

11. Dias, V.V.; Balanzá-Martinez, V.; Soeiro-de-Souza, M.G.; Moreno, R.A.; Figueira, M.L.; Machado-Vieira, R.; Vieta, E. Pharmacological approaches in bipolar disorders and the impact on cognition: A critical overview. Acta Psychiatr. Scand. 2012, 126, 315-331. [CrossRef]

12. Manji, H.K.; Quiroz, J.A.; Payne, J.L.; Singh, J.; Lopes, B.P.; Viegas, J.S.; Zarate, C.A. The underlying neurobiology of bipolar disorder. World Psychiatry 2003, 2, 136.

13. Chee, I.S.; Lee, S.W.; Kim, J.L.; Wang, S.K.; Shin, Y.O.; Shin, S.C.; Lee, Y.H.; Hwang, H.M.; Lim, M.R. 5-HT2A receptor gene promoter polymorphism-1438A/G and bipolar disorder. Psychiatric Genet. 2001, 11, 111-114. [CrossRef]

14. Du, L.; Bakish, D.; Lapierre, Y.D.; Ravindran, A.V.; Hrdina, P.D. Association of polymorphism of serotonin 2A receptor gene with suicidal ideation in major depressive disorder. Am. J. Med. Genet. 2000, 96, 56-60. [CrossRef]

15. Fortinguerra, S.; Buriani, A.; Sorrenti, V.; Lenzi, M.; Giusti, P. Molecular network-selected pharmacogenomics in a case of bipolar spectrum disorder. Pharmacogenomics 2017, 18, 1631-1642. [CrossRef]

16. American Psychiatric Association. Diagnostic and Statistical Manual of Mental Disorders: Diagnostic and Statistical Manual of Mental Disorders, 5th ed.; American Psychiatric Association: Arlington, VA, USA, 2013.

17. Henderson, D.K.; Gillespie, R.D. Textbook of Psychiatry, 6th ed.; Humphrey Milford Oxford University Press: London, UK, 1944; p. 3.

18. Baastrup, P.C.; Schou, M. Lithium as a prophylactic agent: Its effect against recurring depression and manic depressive psychosis. Arch. Gen. Psychiatry 1967, 16, 162-172. [CrossRef]

19. Shen, W.W. Clinical Psychopharmacology in the Twenty-First Century, Revised Edition; Hochi Publishing Company: Taipei, Taiwan, 2004. (In Mandarin)

20. Ramachandraiah, C.T.; Subramaniam, N.; Tancer, M. The story of antipsychotics: Past and present. Indian J. Psychiatry 2009, 51, 324. [CrossRef]

21. Shen, W.W. A history of antipsychotic drug development. Compr. Psychiatry 1999, 40, 407-414. [CrossRef]

22. Seeman, P. Atypical antipsychotics: Mechanism of action. Focus 2004, 47, 27-58. [CrossRef]

23. Malhi, G.S.; Tanious, M.; Das, P.; Coulston, C.M.; Berk, M. Potential mechanisms of action of lithium in bipolar disorder. CNS Drugs 2013, 27, 135-153. [CrossRef]

24. Marmol, F. Lithium: Bipolar disorder and neurodegenerative diseases Possible cellular mechanisms of the therapeutic effects of lithium. Prog. Neuropsychopharmacol. Biol. Psychiatry 2008, 32, 1761-1771. [CrossRef] 
25. Pisanu, C.; Squassina, A.; Alda, M.; Severino, G. Pharmacogenomics of bipolar disorder. In Personalized Psychiatry, 1st ed.; Baune, B., Ed.; Elsevier Academic Press: Amsterdam, The Netherlands, 2019; Chapter 32, ISBN 9780128131763.

26. Spina, E.; Perugi, G. Antiepileptic drugs: Indications other than epilepsy. Epileptic Disord. 2004, 6, 57-75.

27. Landmark, C.J. Antiepileptic drugs in non-epilepsy disorders. CNS Drugs 2008, 22, 27-47. [CrossRef]

28. Friedman, S.D.; Dager, S.R.; Parow, A.; Hirashima, F.; Demopulos, C.; Stoll, A.L.; Lyoo, I.K.; Dunner, D.L.; Renshaw, P.F. Lithium and valproic acid treatment effects on brain chemistry in bipolar disorder. Biol. Psychiatry 2004, 56, 340-348. [CrossRef]

29. Chiu, C.T.; Wang, Z.; Hunsberger, J.G.; Chuang, D.M. Therapeutic potential of mood stabilizers lithium and valproic acid: Beyond bipolar disorder. Pharmacol. Rev. 2013, 65, 105-142. [CrossRef]

30. Macritchie, K.; Geddes, J.; Scott, J.; Haslam, D.R.; Goodwin, G. Valproic acid, valproate and divalproex in the maintenance treatment of bipolar disorder. Cochrane Database Syst. Rev. 2001. [CrossRef]

31. Denicoff, K.D.; Smith-Jackson, E.E.; Disney, E.R.; Ali, S.O.; Leverich, G.S.; Post, R.M. Comparative prophylactic efficacy of lithium, carbamazepine, and the combination in bipolar disorder. J. Clin. Psychiatry 1997, 58, 470-478. [CrossRef]

32. Kowatch, R.A.; Suppes, T.; Carmody, T.J.; Bucci, J.P.; Hume, J.H.; Kromelis, M.; Emslie, G.J.; Weinberg, W.A.; Rush, A.J. Effect size of lithium, divalproex sodium, and carbamazepine in children and adolescents with bipolar disorder. J. Am. Acad. Child. Adolesc. Psychiatry 2000, 39, 713-720. [CrossRef]

33. Tohen, M.; Castillo, J.; Pope, H.G.; Herbstein, J. Concomitant use of valproate and carbamazepine in bipolar and schizoaffective disorders. J. Clin. Psychopharmacol. 1994, 14, 67-70. [CrossRef]

34. Calabrese, J.R.; Bowden, C.L.; Sachs, G.; Yatham, L.N.; Behnke, K.; Mehtonen, O.P.; Montgomery, P.; Ascher, J.; Paska, W.; Earl, N.; et al. A placebo-controlled 18-month trial of lamotrigine and lithium maintenance treatment in recently depressed patients with bipolar I disorder. J. Clin. Psychiatry 2003, 64, 1013-1024. [CrossRef]

35. Lee, C.Y.; Fu, W.M.; Chen, C.C.; Su, M.J.; Liou, H.H. Lamotrigine inhibits postsynaptic AMPA receptor and glutamate release in the dentate gyrus. Epilepsia 2008, 49, 888-897. [CrossRef] [PubMed]

36. Yatham, L.N.; Goldstein, J.M.; Vieta, E.; Bowden, C.L.; Grunze, H.; Post, R.M.; Suppes, T.; Calabrese, J.R. Atypical antipsychotics in bipolar depression: Potential mechanisms of action. J. Clin. Psychiatry 2005, 66, 40-48. [PubMed]

37. Meltzer, H.Y.; Massey, B.W. The role of serotonin receptors in the action of atypical antipsychotic drugs. Curr. Opin. Pharmacol. 2011, 11, 59-67. [CrossRef] [PubMed]

38. Meltzer, H.Y. The mechanism of action of novel antipsychotic drugs. Schizophr. Bull. 1991, 17, $263-287$. [CrossRef]

39. Thase, M.E.; Macfadden, W.; Weisler, R.H.; Chang, W.; Paulsson, B.; Khan, A.; Calabrese, J.R. BOLDER II Study Group. Efficacy of quetiapine monotherapy in bipolar I and II depression: A double-blind, placebo-controlled study (the BOLDER II study). J. Clin. Psychopharmacol. 2006, 26, 600-609. [CrossRef]

40. Fornaro, M.; De Berardis, D.; Perna, G.; Solmi, M.; Veronese, N.; Orsolini, L.; Buonaguro, E.F.; Iasevoli, F.; Köhler, C.A.; Carvalho, A.F.; et al. Lurasidone in the treatment of bipolar depression: Systematic review of systematic reviews. Biomed Res. Int. 2017, 2017, 3084859. [CrossRef]

41. Freeman, M.P.; Freeman, S.A.; McElroy, S.L. The comorbidity of bipolar and anxiety disorders: Prevalence, psychobiology, and treatment issues. J. Affect. Disord. 2002, 68, 1-23. [CrossRef]

42. Ghaemi, S.N.; Boiman, E.E.; Goodwin, F.K. Diagnosing bipolar disorder and the effect of antidepressants: A naturalistic study. J. Clin. Psychiatry 2000, 61. [CrossRef]

43. El-Mallakh, R.S.; Vöhringer, P.A.; Ostacher, M.M.; Baldassano, C.F.; Holtzman, N.S.; Whitham, E.A.; Thommi, S.B.; Goodwin, F.K.; Ghaemi, S.N. Antidepressants worsen rapid-cycling course in bipolar depression: A STEP-BD randomized clinical trial. J. Affect. Disord. 2015, 184, 318-321. [CrossRef]

44. King, S.; Jelen, L.A.; Horne, C.M.; Cleare, A.; Pariante, C.M.; Young, A.H.; Stone, J.M. Inflammation, Glutamate, and Cognition in Bipolar Disorder Type II: A Proof of Concept Study. Front. Psychiatry 2019, 10, 66. [CrossRef]

45. Jun, C.; Choi, Y.; Lim, S.M.; Bae, S.; Hong, Y.S.; Kim, J.E.; Lyoo, I.K. Disturbance of the glutamatergic system in mood disorders. Exp. Neurobiol. 2014, 23, 28-35. [CrossRef] [PubMed] 
46. Kalandadze, A.; Wu, Y.; Robinson, M.B. Protein Kinase C Activation Decreases Cell Surface Expression of the GLT-1 Subtype of Glutamate Transporter requirement of a carboxyl-terminal domain and partial dependence on serine 486. J. Biol. Chem. 2002, 277, 45741-45750. [CrossRef] [PubMed]

47. Guillet, B.A.; Velly, L.J.; Canolle, B.F.M.M.; Masmejean, F.M.; Nieoullon, A.L.; Pisano, P. Differential regulation by protein kinases of activity and cell surface expression of glutamate transporters in neuron-enriched cultures. Neurochem. Int. 2005, 46, 337-346. [CrossRef] [PubMed]

48. Boehmer, C.; Palmada, M.; Rajamanickam, J.; Schniepp, R.; Amara, S.; Lang, F. Post-translational regulation of EAAT2 function by co-expressed ubiquitin ligase Nedd4-2 is impacted by SGK kinases. J. Neurochem. 2006, 97, 911-921. [CrossRef] [PubMed]

49. Sattler, R.; Rothstein, J.D. Regulation and dysregulation of glutamate transporters. In Neurotransmitter Transporters; Springer: Berlin/Heidelberg, Germany, 2006; pp. 277-303.

50. Martínez-Villarreal, J.; García Tardón, N.; Ibáñez, I.; Giménez, C.; Zafra, F. Cell surface turnover of the glutamate transporter GLT-1 is mediated by ubiquitination/deubiquitination. Glia 2012, 60, 1356-1365. [CrossRef]

51. Rang, H.P.; Dale, M.M.; Ritter, J.M.; Moore, P.K. Ch. 10. In Pharmacology, 5th ed.; Elsevier Churchill Livingstone: London, UK, 2010; ISBN 978-0-443-07145-4.

52. González-gonzález, I.M.; García-tardón, N.; Giménez, C.; Zafra, F. PKC-dependent endocytosis of the GLT1 glutamate transporter depends on ubiquitylation of lysines located in a C-terminal cluster. Glia 2008, 56, 963-974. [CrossRef]

53. Reynolds, G.P. Receptor mechanisms of antipsychotic drug action in bipolar disorder-Focus on asenapine. Ther. Adv. Psychopharm. 2011, 1, 197-204. [CrossRef]

54. Smoller, J.W.; Finn, C.T. Family, twin, and adoption studies of bipolar disorder. Am. J. Med. Genet. Part C Semin. Med. Genet. 2003, 123, 48-58. [CrossRef]

55. Stahl, E.A.; Breen, G.; Forstner, A.J.; McQuillin, A.; Ripke, S.; Trubetskoy, V.; Mattheisen, M.; Wang, Y.; Coleman, J.R.; Gaspar, H.A.; et al. Genome-wide association study identifies 30 loci associated with bipolar disorder. Nature Genet. 2019, 51, 793. [CrossRef]

56. Kessler, R.C.; Rubinow, D.R.; Holmes, C.; Abelson, J.M.; Zhao, S. The epidemiology of DSM-III-R bipolar I disorder in a general population survey. Psychol. Med. 1997, 27, 1079-1089. [CrossRef]

57. Gershon, E.S.; Hamovit, J.; Guroff, J.J.; Dibble, E.; Leckman, J.F.; Sceery, W.; Targum, S.D.; Nurnberger, J.I., Jr.; Goldin, L.R.; Bunney, W.E., Jr. A family study of schizoaffective, bipolar I, bipolar II, unipolar, and normal control probands. Arch. Gen. Psychiatry 1982, 39, 1157-1167. [CrossRef] [PubMed]

58. Andreasen, N.C.; Rice, J.; Endicott, J.; Coryell, W.; Grove, W.M.; Reich, T. Familial rates of affective disorder: A report from the National Institute of Mental Health Collaborative Study. Arch. Gen. Psychiatry 1987, 44, 461-469. [CrossRef] [PubMed]

59. Heun, R.; Maier, W. The distinction of bipolar II disorder from bipolar I and recurrent unipolar depression: Results of a controlled family study. Acta Psychiatr. Scand. 1993, 87, 279-284. [CrossRef] [PubMed]

60. Barnett, J.H.; Smoller, J.W. The genetics of bipolar disorder. Neuroscience 2009, 164, 331-343. [CrossRef] [PubMed]

61. Craddock, N.; Sklar, P. Genetics of bipolar disorder. Lancet 2013, 381, 1654-1662. [CrossRef]

62. Ferreira, M.A.; O’Donovan, M.C.; Meng, Y.A.; Jones, I.R.; Ruderfer, D.M.; Jones, L.; Fan, J.; Kirov, G.; Perlis, R.H.; Green, E.K.; et al. Collaborative genome-wide association analysis supports a role for ANK3 and CACNA1C in bipolar disorder. Nature Genet. 2008, 40, 1056. [CrossRef]

63. Psychiatric GWAS Consortium Bipolar Disorder Working Group. Large-scale genome-wide association analysis of bipolar disorder identifies a new susceptibility locus near ODZ4. Nature Genet. 2011, 43, 977. [CrossRef]

64. Saiz-Rodríguez, M.; Belmonte, C.; Román, M.; Ochoa, D.; Jiang-Zheng, C.; Koller, D.; Mejía, G.; Zubiaur, P.; Wojnicz, A.; Abad-Santos, F. Effect of ABCB1 C3435T polymorphism on pharmacokinetics of antipsychotics and antidepressants. Basic. Clin. Pharmacol. Toxicol. 2018, 123, 474-485. [CrossRef]

65. Buriani, A.; Fortinguerra, S.; Carrara, M.; Pelkonen, O. Systems network pharmaco-toxicology in the study of herbal medicines. In Toxicology of Herbal Products; Springer: Cham, Germany, 2017; pp. 129-164.

66. Table of Pharmacogenomic Biomarkers in Drug Labeling (FDA). Available online: https://www.fda. gov/drugs/science-and-research-drugs/table-pharmacogenomic-biomarkers-drug-labeling (accessed on 1 September 2019). 
67. Pharmgkb. Available online: https://www.pharmgkb.org (accessed on 1 September 2019).

68. The DrugBank database. Available online: https://www.drugbank.ca/ (accessed on 1 September 2019).

69. GeneCards®: The Human Gene Database. Available online: https://www.genecards.org/ (accessed on 1 September 2019).

70. Phillips, E.J.; Sukasem, C.; Whirl-Carrillo, M.; Müller, D.J.; Dunnenberger, H.M.; Chantratita, W.; Goldspiel, B.; Chen, Y.T.; Carleton, B.C.; George, A.L., Jr.; et al. Clinical pharmacogenetics implementation consortium guideline for HLA genotype and use of carbamazepine and oxcarbazepine: 2017 update. Clin. Pharmacol. Ther. 2018, 103, 574-581. [CrossRef]

71. Smith, R.M. Advancing psychiatric pharmacogenomics using drug development paradigms. Pharmacogenomics 2017, 18, 1459-1467. [CrossRef]

72. Luzum, J.A.; Pakyz, R.E.; Elsey, A.R.; Haidar, C.E.; Peterson, J.F.; Whirl-Carrillo, M.; Handelman, S.K.; Palmer, K.; Pulley, J.M.; Beller, M.; et al. The Pharmacogenomics Research Network Translational Pharmacogenetics Program: Outcomes and metrics of pharmacogenetic implementations across diverse healthcare systems. Clin. Pharmacol. Ther. 2017, 102, 502-510. [CrossRef]

73. Mas, S.; Gassó, P.; Lafuente, A.; Bioque, M.; Lobo, A.; Gonzàlez-Pinto, A.; Olmeda, M.S.; Corripio, I.; Llerena, A.; Cabrera, B.; et al. Pharmacogenetic study of antipsychotic induced acute extrapyramidal symptoms in a first episode psychosis cohort: Role of dopamine, serotonin and glutamate candidate genes. Pharmacogenom. J. 2016, 16, 439. [CrossRef]

74. Taylor, S. Association between COMT Val158Met and psychiatric disorders: A comprehensive meta-analysis. Am. J. Med. Genet. B Neuropsychiatr. Genet. 2018, 177, 199-210. [CrossRef]

75. Al Maruf, A.; Greenslade, A.; Arnold, P.D.; Bousman, C. Antidepressant pharmacogenetics in children and young adults: A systematic review. J. Affect. Disord. 2019, 254, 98-108. [CrossRef]

76. Serretti, A.; Calati, R.; Mandelli, L.; De Ronchi, D. Serotonin transporter gene variants and behavior: A comprehensive review. Curr. Drug Targets 2006, 7, 1659-1669. [CrossRef]

77. Qesseveur, G.; Petit, A.C.; Nguyen, H.T.; Dahan, L.; Colle, R.; Rotenberg, S.; Seif, I.; Robert, P.; David, D.; Guilloux, J.P.; et al. Genetic dysfunction of serotonin 2A receptor hampers response to antidepressant drugs: A translational approach. Neuropharmacology 2016, 105, 142-153. [CrossRef]

78. Lin, J.Y.; Jiang, M.Y.; Kan, Z.M.; Chu, Y. Influence of 5-HTR2A genetic polymorphisms on the efficacy of antidepressants in the treatment of major depressive disorder: A meta-analysis. J. Affect. Disord. 2014, 168, 430-438. [CrossRef]

79. Niitsu, T.; Fabbri, C.; Bentini, F.; Serretti, A. Pharmacogenetics in major depression: A comprehensive meta-analysis. Prog. Neuropsychopharmacol. Biol. Psychiatry 2013, 45, 183-194. [CrossRef]

80. Kishi, T.; Yoshimura, R.; Fukuo, Y.; Okochi, T.; Matsunaga, S.; Umene-Nakano, W.; Nakamura, J.; Serretti, A.; Correll, C.U.; Kane, J.M.; et al. The serotonin 1A receptor gene confer susceptibility to mood disorders: Results from an extended meta-analysis of patients with major depression and bipolar disorder. Eur. Arch. Psychiatry Clin. Neurosci. 2013, 263, 105-118. [CrossRef]

81. Illi, A.; Setälä-Soikkeli, E.; Viikki, M.; Poutanen, O.; Huhtala, H.; Mononen, N.; Lehtimäki, T.; Leinonen, E.; Kampman, O. HTR1A, 5-HTR2A, 5-HTR6, TPH1 and TPH2 polymorphisms and major depression. Neuroreport 2009, 20, 1125-1128. [CrossRef]

82. Risselada, A.J.; Vehof, J.; Bruggeman, R.; Wilffert, B.; Cohen, D.; Al Hadithy, A.F.; Arends, J.; Mulder, H. Association between HTR2C gene polymorphisms and the metabolic syndrome in patients using antipsychotics: A replication study. Pharmacogenom. J. 2012, 12, 62. [CrossRef]

83. Rico-Gomis, J.M.; Palazón-Bru, A.; Triano-García, I.; Mahecha-García, L.F.; García-Monsalve, A.; Navarro-Ruiz, A.; Villagordo-Peñalver, B.; Jiménez-Abril, J.; Martínez-Hortelano, A.; Francisco Gil-Guillén, V. Association between the HTR2C rs1414334 C/G gene polymorphism and the development of the metabolic syndrome in patients treated with atypical antipsychotics. PeerJ 2016, 4, e2163. [CrossRef]

84. Zhang, J.P.; Robinson, D.G.; Gallego, J.A.; John, M.; Yu, J.; Addington, J.; Tohen, M.; Kane, J.M.; Malhotra, A.K.; Lencz, T. Association of a schizophrenia risk variant at the DRD2 locus with antipsychotic treatment response in first-episode psychosis. Schizophr. Bull. 2015, 41, 1248-1255. [CrossRef]

85. Eum, S.; Schneiderhan, M.E.; Brown, J.T.; Lee, A.M.; Bishop, J.R. Pharmacogenetic evaluation to assess breakthrough psychosis with aripiprazole long-acting injection: A case report. BMC Psychiatry 2017, 17, 238. [CrossRef] 
86. Zhang, J.P.; Lencz, T.; Malhotra, A.K. D2 receptor genetic variation and clinical response to antipsychotic drug treatment: A meta-analysis. Am. J. Psychiatry 2010, 167, 763-772. [CrossRef]

87. Keers, R.; Bonvicini, C.; Scassellati, C.; Uher, R.; Placentino, A.; Giovannini, C.; Rietschel, M.; Henigsberg, N.; Kozel, D.; Mors, O. Variation in GNB3 predicts response and adverse reactions to antidepressants. J. Psychopharmacol. 2011, 25, 867-874. [CrossRef]

88. Amare, A.T.; Schubert, K.O.; Hou, L.; Clark, S.R.; Papiol, S.; Heilbronner, U.; Degenhardt, F.; Tekola-Ayele, F.; Hsu, Y.H.; Shekhtman, T.; et al. Association of polygenic score for schizophrenia and HLA antigen and inflammation genes with response to lithium in bipolar affective disorder: A genome-wide association study. JAMA Psychiatry 2018, 75, 65-74.

89. van Huis-Tanja, L.H.; Ewing, E.; van der Straaten, R.J.H.M.; Swen, J.J.; Baak-Pablo, R.F.; Punt, C.J.A.; Gelderblom, A.J.; Guchelaar, H.J. Clinical validation study of genetic markers for capecitabine efficacy in metastatic colorectal cancer patients. Pharmacogenet. Genom. 2015, 25, 279-288. [CrossRef]

90. Clark, S.L.; Souza, R.P.; Adkins, D.E.; Åberg, K.; Bukszár, J.; McClay, J.L.; Sullivan, P.F.; van den Oord, E.J. Genome-wide association study of patient and clinician rated global impression severity during antipsychotic treatment. Pharmacogenet. Genom. 2013, 23, 69. [CrossRef]

91. Almoguera, B.; Riveiro-Alvarez, R.; López-Castromán, J.; Dorado, P.; Vaquero-Lorenzo, C.; Fernandez-Piqueras, J.; Llerena, A.; Abad-Santos, F.; Baca-García, E.; Dal-Ré, R.; et al. Association of common genetic variants with risperidone adverse events in a Spanish schizophrenic population. Pharmacogenom. J. 2013, 13, 197. [CrossRef]

92. Ikeda, M.; Yamanouchi, Y.; Kinoshita, Y.; Kitajima, T.; Yoshimura, R.; Hashimoto, S.; O’Donovan, M.C.; Nakamura, J.; Ozaki, N.; Iwata, N. Variants of dopamine and serotonin candidate genes as predictors of response to risperidone treatment in first-episode schizophrenia. Pharmacogenomics 2008, 9, 1437-1443. [CrossRef]

93. López-Rodríguez, R.; Cabaleiro, T.; Ochoa, D.; Román, M.; Borobia, A.M.; Carcas, A.J.; Ayuso, C.; Novalbos, J.; Abad-Santos, F. Pharmacodynamic genetic variants related to antipsychotic adverse reactions in healthy volunteers. Pharmacogenomics 2013, 14, 1203-1214. [CrossRef]

94. Squassina, A.; Manchia, M.; Borg, J.; Congiu, D.; Costa, M.; Georgitsi, M.; Chillotti, C.; Ardau, R.; Mitropoulos, K.; Severino, G.; et al. Evidence for association of an ACCN1 gene variant with response to lithium treatment in Sardinian patients with bipolar disorder. Pharmacogenomics 2011, 12, 1559-1569. [CrossRef]

95. Lane, H.Y.; Liu, Y.C.; Huang, C.L.; Chang, Y.C.; Wu, P.L.; Lu, C.T.; Chang, W.H. Risperidone-related weight gain: Genetic and nongenetic predictors. J. Clin. Psychopharmacol. 2006, 26, 128-134. [CrossRef]

96. Anttila, V.; Winsvold, B.S.; Gormley, P.; Kurth, T.; Bettella, F.; McMahon, G.; Kallela, M.; Malik, R.; de Vries, B.; Terwindt, G.; et al. Genome-wide meta-analysis identifies new susceptibility loci for migraine. Nat. Genet. 2013, 45, 912. [CrossRef]

97. Silberberg, G.; Levit, A.; Collier, D.; Clair, D.S.; Munro, J.; Kerwin, R.W.; Tondo, L.; Floris, G.; Breen, G.; Navon, R. Stargazin involvement with bipolar disorder and response to lithium treatment. Pharmacogenet. Genom. 2008, 18, 403-412. [CrossRef]

98. Xiong, Y.; Wei, Z.; Huo, R.; Wu, X.; Shen, L.; Li, Y.; Shao, L.; Li, J.; Zeng, Z.; Li, T.; et al. A pharmacogenetic study of risperidone on chemokine (C-C motif) ligand 2 (CCL2) in Chinese Han schizophrenia patients. Prog. Neuropsychopharmacol. Biol. Psychiatry 2014, 51, 153-158. [CrossRef]

99. Nurmi, E.L.; Spilman, S.L.; Whelan, F.; Scahill, L.L.; Aman, M.G.; McDougle, C.J.; Arnold, L.E.; Handen, B.; Johnson, C.; Sukhodolsky, D.G.; et al. Moderation of antipsychotic-induced weight gain by energy balance gene variants in the RUPP autism network risperidone studies. Transl. Psychiatry 2013, 3, e274. [CrossRef]

100. Vázquez-Bourgon, J.; Arranz, M.J.; Mata, I.; Pelayo-Terán, J.M.; Pérez-Iglesias, R.; Medina-González, L.; Carrasco-Marín, E.; Vázquez-Barquero, J.L.; Crespo-Facorro, B. Serotonin transporter polymorphisms and early response to antipsychotic treatment in first episode of psychosis. Psychiatr. Res. 2010, 175, 189-194. [CrossRef]

101. Xu, Q.; Wu, X.; Li, M.; Huang, H.; Minica, C.; Yi, Z.; Wang, G.; Shen, L.; Xing, Q.; Shi, Y.; et al. Association studies of genomic variants with treatment response to risperidone, clozapine, quetiapine and chlorpromazine in the Chinese Han population. Pharmacogenom. J. 2016, 16, 357. [CrossRef] 
102. Drugs@FDA: Drug Product Depakene (Valproic Acid), NDA018081, REMEDYREPACK INC. Available online: https://www.accessdata.fda.gov/scripts/cder/daf/index.cfm?event=overview.process\&varApplNo= 018081 (accessed on 1 September 2019).

103. Terzić, T.; Kastelic, M.; Dolžan, V.; Kores Plesničar, B. Genetic polymorphisms in dopaminergic system and treatment-resistant schizophrenia. Psychiatr. Danub. 2016, 28, 127-131.

104. Hong, C.J.; Liou, Y.J.; Bai, Y.M.; Chen, T.T.; Wang, Y.C.; Tsai, S.J. Dopamine receptor D2 gene is associated with weight gain in schizophrenic patients under long-term atypical antipsychotic treatment. Pharmacogenet. Genom. 2010, 20, 359-366. [CrossRef]

105. Lencz, T.; Robinson, D.G.; Xu, K.; Ekholm, J.; Sevy, S.; Gunduz-Bruce, H.; Woerner, M.G.; Kane, J.M.; Goldman, D.; Malhotra, A.K. DRD2 promoter region variation as a predictor of sustained response to antipsychotic medication in first-episode schizophrenia patients. Am. J. Psychiatry 2006, 163, 529-531. [CrossRef]

106. Cabaleiro, T.; López-Rodríguez, R.; Román, M.; Ochoa, D.; Novalbos, J.; Borobia, A.; Carcas, A.; Abad-Santos, F. Pharmacogenetics of quetiapine in healthy volunteers: Association with pharmacokinetics, pharmacodynamics, and adverse effects. Int. Clin. Psychopharmacol. 2015, 30, 82-88. [CrossRef]

107. Perlis, R.H.; Fijal, B.; Dharia, S.; Houston, J.P. Pharmacogenetic investigation of response to duloxetine treatment in generalized anxiety disorder. Pharmacogenom. J. 2013, 13, 280. [CrossRef]

108. Porcelli, S.; Balzarro, B.; Lee, S.J.; Han, C.; Patkar, A.A.; Pae, C.U.; Serretti, A. PDE7B, NMBR and EPM2A variants and schizophrenia: A case-control and pharmacogenetics study. Neuropsychobiology 2016, 73, 160-168. [CrossRef]

109. Monteleone, P.; Milano, W.; Petrella, C.; Canestrelli, B.; Maj, M. Endocannabinoid Pro129Thr FAAH functional polymorphism but not 1359G/A CNR1 polymorphism is associated with antipsychotic-induced weight gain. J. Clin. Psychopharmacol. 2010, 30, 441-445. [CrossRef]

110. Mao, Y.M.; Liu, Z.Q.; Chen, B.L.; Guo, D.; Han, C.T.; Yang, L.J.; Wang, S.Y.; Fan, L.; Zhou, H.H. Effect of 393T> C polymorphism of GNAS1 gene on dobutamine response in Chinese healthy subjects. J. Clin. Pharmacol. 2009, 49, 929-936. [CrossRef]

111. Alakus, H.; Warnecke-Eberz, U.; Bollschweiler, E.; Mönig, S.P.; Vallböhmer, D.; Brabender, J.; Drebber, U.; Baldus, S.E.; Riemann, K.; Siffert, W.; et al. GNAS1 T393C polymorphism is associated with histopathological response to neoadjuvant radiochemotherapy in esophageal cancer. Pharmacogenom. J. 2009, 9, 202. [CrossRef]

112. Noordam, R.; Direk, N.; Sitlani, C.M.; Aarts, N.; Tiemeier, H.; Hofman, A. Identifying genetic loci associated with antidepressant drug response with drug-gene interaction models in a population-based study. J. Psychiatr. Res. 2015, 62, 31-37. [CrossRef]

113. Balan, S.; Sathyan, S.; Radha, S.K.; Joseph, V.; Radhakrishnan, K.; Banerjee, M. GABRG2, rs211037 is associated with epilepsy susceptibility, but not with antiepileptic drug resistance and febrile seizures. Pharmacogenet. Genom. 2013, 23, 605-610. [CrossRef]

114. Chen, C.H.; Lee, C.S.; Lee, M.T.M.; Ouyang, W.C.; Chen, C.C.; Chong, M.Y.; Wu, J.Y.; Tan, H.K.; Lee, Y.C.; Chuo, L.J.; et al. Variant GADL1 and response to lithium therapy in bipolar I disorder. N. Engl. J. Med. 2014, 370, 119-128. [CrossRef]

115. Wang, L.; Fang, C.; Zhang, A.; Du, J.; Yu, L.; Ma, J.; Feng, G.; Xing, Q.; He, L. The-1019 C/G polymorphism of the 5-HT1A receptor gene is associated with negative symptom response to risperidone treatment in schizophrenia patients. J. Clin. Psychopharmacol. 2008, 22, 904-909. [CrossRef]

116. Stevenson, J.M.; Reilly, J.L.; Harris, M.S.H.; Patel, S.R.; Weiden, P.J.; Prasad, K.M.; Badner, J.A.; Nimgaonkar, V.L.; Keshavan, M.S.; Sweeney, J.A.; et al. Antipsychotic pharmacogenomics in first episode psychosis: A role for glutamate genes. Transl. Psychiatry 2016, 6, e739. [CrossRef]

117. Hung, C.C.; Ho, J.L.; Chang, W.L.; Tai, J.J.; Hsieh, T.J.; Hsieh, Y.W.; Liou, H.H. Association of genetic variants in six candidate genes with valproic acid therapy optimization. Pharmacogenomics 2011, 12, 1107-1117. [CrossRef]

118. Fijal, B.A.; Kinon, B.J.; Kapur, S.; Stauffer, V.L.; Conley, R.R.; Jamal, H.H.; Kane, J.M.; Witte, M.M.; Houston, J.P. Candidate-gene association analysis of response to risperidone in African-American and white patients with schizophrenia. Pharmacogenom. J. 2009, 9, 311. [CrossRef]

119. Lin, Y.F.; Huang, M.C.; Liu, H.C. Glycogen synthase kinase $3 \beta$ gene polymorphisms may be associated with bipolar I disorder and the therapeutic response to lithium. J. Affect. Disord. 2013, 147, 401-406. [CrossRef] 
120. Li, L.J.; Hu, F.Y.; Wu, X.T.; An, D.M.; Yan, B.; Zhou, D. Predictive markers for carbamazepine and lamotrigine-induced maculopapular exanthema in Han Chinese. Epilepsy Res. 2013, 106, 296-300. [CrossRef]

121. Koomdee, N.; Pratoomwun, J.; Jantararoungtong, T.; Theeramoke, V.; Tassaneeyakul, W.; Klaewsongkram, J.; Rerkpattanapipat, T.; Santon, S.; Puangpetch, A.; Intusoma, U.; et al. Association of HLA-A and HLA-B alleles with lamotrigine-induced cutaneous adverse drug reactions in the Thai population. Front. Pharmacol. 2017, 8, 879. [CrossRef]

122. Kazeem, G.R.; Cox, C.; Aponte, J.; Messenheimer, J.; Brazell, C.; Nelsen, A.C. High-resolution HLA genotyping and severe cutaneous adverse reactions in lamotrigine-treated patients. Pharmacogenet. Genom. 2009, 19, 661-665. [CrossRef]

123. Chen, Z.; Liew, D.; Kwan, P. Real-world cost-effectiveness of pharmacogenetic screening for epilepsy treatment. Neurology 2016, 86, 1086-1094. [CrossRef]

124. Ramírez, E.; Bellón, T.; Tong, H.Y.; Borobia, A.M.; de Abajo, F.J.; Lerma, V.; Hidalgo, M.A.; Castañer, J.L.; Cabañas, R.; Fiandor, A.; et al. Significant HLA class I type associations with aromatic antiepileptic drug (AED)-induced SJS/TEN are different from those found for the same AED-induced DRESS in the Spanish population. Pharmacol. Res. 2017, 115, 168-178. [CrossRef]

125. Drugs@FDA: Drug Product Tegretol (Carbamazepine), NDA016608, REMEDYREPACK INC. Available online: https://www.accessdata.fda.gov/scripts/cder/daf/index.cfm?event=overview.process\&varApplNo= 016608 (accessed on 1 September 2019).

126. Wei, Z.; Wang, L.; Zhang, M.; Xuan, J.; Wang, Y.; Liu, B.; Shao, L.; Li, J.; Zeng, Z.; Li, T.; et al. A pharmacogenetic study of risperidone on histamine $\mathrm{H} 3$ receptor gene (HRH3) in Chinese Han schizophrenia patients. J. Psychopharmacol. 2012, 26, 813-818. [CrossRef]

127. Wei, Z.; Wang, L.; Yu, T.; Wang, Y.; Sun, L.; Wang, T.; Huo, R.; Li, Y.; Wu, X.; Qin, S.; et al. Histamine H4 receptor polymorphism: A potential predictor of risperidone efficacy. J. Clin. Psychopharmacol. 2013, 33, 221-225. [CrossRef]

128. Crisafulli, C.; Chiesa, A.; Han, C.; Lee, S.J.; Park, M.H.; Balzarro, B.; Andrisano, C.; Patkar, A.A.; Pae, C.U.; Serretti, A. Case-control association study for 10 genes in patients with schizophrenia: Influence of 5HTR1A variation rs10042486 on schizophrenia and response to antipsychotics. Eur. Arch. Psychiatry Clin. Neurosci. 2012, 262, 199-205. [CrossRef]

129. Kato, M.; Fukuda, T.; Wakeno, M.; Okugawa, G.; Takekita, Y.; Watanabe, S.; Yamashita, M.; Hosoi, Y.; Azuma, J.; Kinoshita, T.; et al. Effect of 5-HT1A gene polymorphisms on antidepressant response in major depressive disorder. Am. J. Med. Genet. B Neuropsychiatr. Genet. 2009, 150, 115-123. [CrossRef]

130. Correia, C.T.; Almeida, J.P.; Santos, P.E.; Sequeira, A.F.; Marques, C.E.; Miguel, T.S.; Abreu, R.L.; Oliveira, G.G.; Vicente, A.M. Pharmacogenetics of risperidone therapy in autism: Association analysis of eight candidate genes with drug efficacy and adverse drug reactions. Pharmacogenom. J. 2010, 10, 418. [CrossRef]

131. Opgen-Rhein, C.; Brandl, E.J.; Müller, D.J.; Neuhaus, A.H.; Tiwari, A.K.; Sander, T.; Dettling, M. Association of HTR2C, but not LEP or INSIG2, genes with antipsychotic-induced weight gain in a German sample. Pharmacogenomics 2010, 11, 773-780. [CrossRef]

132. Puangpetch, A.; Unaharassamee, W.; Jiratjintana, N.; Koomdee, N.; Sukasem, C. Genetic polymorphisms of HTR 2C, LEP and LEPR on metabolic syndromes in patients treated with atypical antipsychotic drugs. J. Pharm. Pharmacol. 2018, 70, 536-542. [CrossRef]

133. Rico-Gomis, J.M.; Palazón-Bru, A.; Triano-García, I.; Fabián, L. Relationship between the rs1414334 C/G polymorphism in the HTR2C gene and smoking in patients treated with atypical antipsychotics. Adicciones 2018, 30, 123-130. [CrossRef]

134. Liu, B.C.; Zhang, J.; Wang, L.; Li, X.W.; Wang, Y.; Wei, Z.Y.; Ji, J.; Yang, F.P.; Wan, C.L.; Xu, Y.; et al. FHTR2C promoter polymorphisms are associated with risperidone efficacy in Chinese female patients. Pharmacogenomics 2010, 11, 685-692. [CrossRef]

135. Ruaño, G.; Thompson, P.D.; Windemuth, A.; Seip, R.L.; Dande, A.; Sorokin, A.; Kocherla, M.; Smith, A.; Holford, T.R.; Wu, A.H. Physiogenomic association of statin-related myalgia to serotonin receptors. Muscle Nerve 2007, 36, 329-335. [CrossRef]

136. Liu, Q.; Jamba, M.; Patrick, C., III; Padmanabhan, S.; Brennan, M.D. Targeted pharmacogenetic analysis of antipsychotic response in the CATIE study. Pharmacogenomics 2012, 13, 1227-1237. [CrossRef] 
137. Srivastava, V.; Deshpande, S.N.; Nimgaonkar, V.L.; Lerer, B.; Thelma, B.K. Genetic correlates of olanzapine-induced weight gain in schizophrenia subjects from north India: Role of metabolic pathway genes. Pharmacogenomics 2008, 1055-1068. [CrossRef]

138. Calarge, C.A.; Ellingrod, V.L.; Zimmerman, B.; Acion, L.; Sivitz, W.I.; Schlechte, J.A. Leptin promoter-2548G/A variants predict risperidone-associated weight gain in children and adolescents. Psychiat. Genet. 2009, 19, 320. [CrossRef]

139. Li, H.; Wang, X.; Zhou, Y.; Ni, G.; Su, Q.; Chen, Z.; Li, J.; Chen, X.; Hou, X.; Xie, W.; et al. Association of LEPR and ANKK1 gene polymorphisms with weight gain in epilepsy patients receiving valproic acid. Int. J. Neuropsychoph. 2015, 18. [CrossRef]

140. Malhotra, A.K.; Correll, C.U.; Chowdhury, N.I.; Müller, D.J.; Gregersen, P.K.; Lee, A.T.; Tiwari, A.K.; Kane, J.M.; Fleischhacker, W.W.; Kahn, R.S.; et al. Association between common variants near the melanocortin 4 receptor gene and severe antipsychotic drug-induced weight gain. Arch. Gen. Psychiatry 2012, 69, 904-912. [CrossRef]

141. Czerwensky, F.; Leucht, S.; Steimer, W. MC4R rs489693: A clinical risk factor for second generation antipsychotic-related weight gain? Int. J. Neuropsychopharmacol. 2013, 16, 2103-2109. [CrossRef]

142. Campos-de-Sousa, S.; Guindalini, C.; Tondo, L.; Munro, J.; Osborne, S.; Floris, G.; Pedrazzoli, M.; Tufik, S.; Breen, G.; Collier, D. Nuclear receptor Rev-Erb- $\alpha$ circadian gene variants and lithium carbonate prophylaxis in bipolar affective disorder. J. Biol. Rhythms 2010, 25, 132-137. [CrossRef]

143. McCarthy, M.J.; Nievergelt, C.M.; Shekhtman, T.; Kripke, D.F.; Welsh, D.K.; Kelsoe, J.R. Functional genetic variation in the Rev-Erb $\alpha$ pathway and lithium response in the treatment of bipolar disorder. Genes Brain Behav. 2011, 10, 852-861. [CrossRef]

144. Choong, E.; Polari, A.; Kamdem, R.H.; Gervasoni, N.; Spisla, C.; Sirot, E.J.; Bickel, G.G.; Bondolfi, G.; Conus, P.; Eap, C.B. Pharmacogenetic study on risperidone long-acting injection: Influence of cytochrome P450 2D6 and pregnane $\mathrm{X}$ receptor on risperidone exposure and drug-induced side-effects. J. Clin. Psychopharmacol. 2013, 33, 289-298. [CrossRef]

145. Vandenberghe, F.; Guidi, M.; Choong, E.; von Gunten, A.; Conus, P.; Csajka, C.; Eap, C.B. Genetics-based population pharmacokinetics and pharmacodynamics of risperidone in a psychiatric cohort. Clin. Pharmacokinet. 2015, 54, 1259-1272. [CrossRef]

146. Wang, Z.; Fan, J.; Gao, K.; Li, Z.; Yi, Z.; Wang, L.; Huang, J.; Yuan, C.; Hong, W.; Yu, S.; et al. Neurotrophic tyrosine kinase receptor type 2 (NTRK2) gene associated with treatment response to mood stabilizers in patients with bipolar I disorder. J. Mol. Neurosci. 2013, 50, 305-310. [CrossRef]

147. Lane, H.Y.; Liu, Y.C.; Huang, C.L.; Chang, Y.C.; Wu, P.L.; Huang, C.H.; Tsai, G.E. RGS4 polymorphisms predict clinical manifestations and responses to risperidone treatment in patients with schizophrenia. J. Clin. Psychopharmacol. 2008, 28, 64-68. [CrossRef]

148. Campbell, D.B.; Ebert, P.J.; Skelly, T.; Stroup, T.S.; Lieberman, J.; Levitt, P.; Sullivan, P.F. Ethnic stratification of the association of RGS4 variants with antipsychotic treatment response in schizophrenia. Biol. Psychiatry 2008, 63, 32-41. [CrossRef]

149. Need, A.C.; Keefe, R.S.; Ge, D.; Grossman, I.; Dickson, S.; McEvoy, J.P.; Goldstein, D.B. Pharmacogenetics of antipsychotic response in the CATIE trial: A candidate gene analysis. Eur. J. Hum. Genet. 2009, 17, 946. [CrossRef]

150. Kumari, R.; Lakhan, R.; Garg, R.K.; Kalita, J.; Misra, U.K.; Mittal, B. Pharmacogenomic association study on the role of drug metabolizing, drug transporters and drug target gene polymorphisms in drug-resistant epilepsy in a north Indian population. Indian J. Hum. Genet. 2011, 17 (Suppl. 1), S32.

151. Daci, A.; Beretta, G.; Vllasaliu, D.; Shala, A.; Govori, V.; Norata, G.D.; Krasniqi, S. Polymorphic variants of SCN1A and EPHX1 influence plasma carbamazepine concentration, metabolism and pharmacoresistance in a population of Kosovar Albanian epileptic patients. PLoS ONE 2015, 10, e0142408. [CrossRef]

152. Thompson, C.H.; Kahlig, K.M.; George, A.L., Jr. SCN1A splice variants exhibit divergent sensitivity to commonly used antiepileptic drugs. Epilepsia 2011, 52, 1000-1009. [CrossRef]

153. Haerian, B.S.; Baum, L.; Kwan, P.; Tan, H.J.; Raymond, A.A.; Mohamed, Z. SCN1A, SCN2A and SCN3A gene polymorphisms and responsiveness to antiepileptic drugs: A multicenter cohort study and meta-analysis. Pharmacogenomics 2013, 14, 1153-1166. [CrossRef] 
154. Kwan, P.; Poon, W.S.; Ng, H.K.; Kang, D.E.; Wong, V.; Ng, P.W.; Lui, C.H.; Sin, N.C.; Wong, K.S.; Baum, L. Multidrug resistance in epilepsy and polymorphisms in the voltage-gated sodium channel genes SCN1A, SCN2A, and SCN3A: Correlation among phenotype, genotype, and mRNA expression. Pharmacogenet. Genom. 2008, 18, 989-998. [CrossRef]

155. Kwon, J.S.; Joo, Y.H.; Nam, H.J.; Lim, M.; Cho, E.Y.; Jung, M.H.; Choi, J.S.; Kim, B.; Kang, D.H.; Oh, S.; et al. Association of the glutamate transporter gene slc1a1 with atypical antipsychotics-Induced obsessive-compulsive symptoms. Arch. Gen. Psychiatry 2009, 66, 1233-1241. [CrossRef]

156. Zai, C.C.; Tiwari, A.K.; Mazzoco, M.; de Luca, V.; Müller, D.J.; Shaikh, S.A.; Lohoff, F.W.; Freeman, N.; Voineskos, A.N.; Potkin, S.G.; et al. Association study of the vesicular monoamine transporter gene SLC18A2 with tardive dyskinesia. J. Psychiatr. Res. 2013, 47, 1760-1765. [CrossRef]

157. Hongkaew, Y.; Medhasi, S.; Pasomsub, E.; Ngamsamut, N.; Puangpetch, A.; Vanwong, N.; Chamnanphon, M.; Limsila, P.; Suthisisang, C.; Wilffert, B.; et al. UGT1A1 polymorphisms associated with prolactin response in risperidone-treated children and adolescents with autism spectrum disorder. Pharmacogenom. J. 2018, 18, 740. [CrossRef]

158. Serretti, A.; Pae, C.U.; Chiesa, A.; Mandelli, L.; De Ronchi, D. Influence of TAAR6 polymorphisms on response to aripiprazole. Prog. Neuropsychopharmacol. Biol. Psychiatry 2009, 33, 822-826. [CrossRef]

159. Ma, J.Z.; Beuten, J.; Payne, T.J.; Dupont, R.T.; Elston, R.C.; Li, M.D. Haplotype analysis indicates an association between the DOPA decarboxylase (DDC) gene and nicotine dependence. Hum. Mol. Genet. 2005, 14, 1691-1698. [CrossRef]

160. Tzvetkov, M.V.; Brockmöller, J.; Roots, I.; Kirchheiner, J. Common genetic variations in human brain-specific tryptophan hydroxylase-2 and response to antidepressant treatment. Pharmacogenet. Genom. 2008, 18, 495-506. [CrossRef]

161. Relling, M.V.; Klein, T.E. CPIC: Clinical pharmacogenetics implementation consortium of the pharmacogenomics research network. Clin. Pharmacol. Ther. 2011, 89, 464-467. [CrossRef]

162. Hicks, J.K.; Swen, J.J.; Thorn, C.F.; Sangkuhl, K.; Kharasch, E.D.; Ellingrod, V.L.; Skaar, T.C.; Müller, D.J.; Gaedigk, A.; Sting, J.C. Clinical Pharmacogenetics Implementation Consortium. Clinical Pharmacogenetics Implementation Consortium guideline for CYP2D6 and CYP2C19 genotypes and dosing of tricyclic antidepressants. Clin. Pharmacol. Ther. 2013, 93, 402-408. [CrossRef]

163. Gross, T.; Daniel, J. Overview of pharmacogenomic testing in clinical practice. Ment. Health Clin. 2018, 8 , 235-241. [CrossRef]

164. Grover, S.; Bala, K.; Sharma, S.; Gourie-Devi, M.; Baghel, R.; Kaur, H.; Gupta, M.; Talwar, P.; Kukreti, R. Absence of a general association between ABCB1 genetic variants and response to antiepileptic drugs in epilepsy patients. Biochimie 2010, 92, 1207-1212. [CrossRef]

165. Kuzman, M.R.; Medved, V.; Bozina, N.; Hotujac, L.; Sain, I.; Bilusic, H. The influence of 5-HT2C and MDR1 genetic polymorphisms on antipsychotic-induced weight gain in female schizophrenic patients. Psychiatry Res. 2008, 160, 308-315. [CrossRef]

166. Suzuki, Y.; Tsuneyama, N.; Fukui, N.; Sugai, T.; Watanabe, J.; Ono, S.; Saito, M.; Inoue, Y.; Someya, T. Effect of risperidone metabolism and P-glycoprotein gene polymorphism on QT interval in patients with schizophrenia. Pharmacogenom. J. 2014, 14, 452. [CrossRef]

167. Wang, R.; Sun, X.; Deng, Y.S.; Qiu, X.W. ABCB1 1199G> A Polymorphism impacts transport ability of P-gp-mediated antipsychotics. DNA Cell Biol. 2018, 37, 325-329. [CrossRef]

168. Mi, W.; Liu, F.; Liu, Y.; Du, B.; Xiao, W.; Li, L.; Huang, L.; Lu, T.; He, J.; Shi, L.; et al. Association of ABCB1 gene polymorphisms with efficacy and adverse reaction to risperidone or paliperidone in Han Chinese schizophrenic patients. Neurosci. Bull. 2016, 32, 547-549. [CrossRef]

169. Zhou, Y.; Wang, X.; Li, H.; Zhang, J.; Chen, Z.; Xie, W.; Zhang, J.; Li, J.; Zhou, L.; Huang, M. Polymorphisms of ABCG2, ABCB1 and HNF4 $\alpha$ are associated with Lamotrigine trough concentrations in epilepsy patients. Drug. Metab. Pharmacokinet. 2015, 30, 282-287. [CrossRef]

170. Rafaniello, C.; Sessa, M.; Bernardi, F.F.; Pozzi, M.; Cheli, S.; Cattaneo, D. The predictive value of ABCB1, ABCG2, CYP3A4/5 and CYP2D6 polymorphisms for risperidone and aripiprazole plasma concentrations and the occurrence of adverse drug reactions. Pharmacogenom. J. 2018, 18, 422. [CrossRef]

171. Wen, Z.P.; Fan, S.S.; Du, C.; Yin, T.; Zhou, B.T.; Peng, Z.F.; Xie, Y.Y.; Zhang, W.; Chen, Y.; Tang, J.; et al. Influence of acylpeptide hydrolase polymorphisms on valproic acid level in Chinese epilepsy patients. Pharmacogenomics 2016, 17, 1219-1225. [CrossRef] 
172. Grover, S.; Talwar, P.; Gourie-Devi, M.; Gupta, M.; Bala, K.; Sharma, S.; Baghel, R.; Kaur, H.; Sharma, A.; Kukreti, R. Genetic polymorphisms in sex hormone metabolizing genes and drug response in women with epilepsy. Pharmacogenomics 2010, 11, 1525-1534. [CrossRef]

173. Tan, L.; Yu, J.T.; Sun, Y.P.; Ou, J.R.; Song, J.H.; Yu, Y. The influence of cytochrome oxidase CYP2A6, CYP2B6, and CYP2C9 polymorphisms on the plasma concentrations of valproic acid in epileptic patients. Clin. Neurol. Neurosurg. 2010, 112, 320-323. [CrossRef]

174. Tay, J.K.; Tan, C.H.; Chong, S.A.; Tan, E.C. Functional polymorphisms of the cytochrome P450 1A2 (CYP1A2) gene and prolonged QTc interval in schizophrenia. Prog. Neuropsychopharmacol. Biol. Psychiatry 2007, 31, 1297-1302. [CrossRef]

175. Hodgson, K.; Tansey, K.; Dernovšek, M.Z.; Hauser, J.; Henigsberg, N.; Maier, W.; Mors, O.; Placentino, A.; Rietschel, M.; Souery, D.; et al. Genetic differences in cytochrome P450 enzymes and antidepressant treatment response. J. Psychopharmacol. 2014, 28, 133-141. [CrossRef]

176. Grasmäder, K.; Verwohlt, P.L.; Rietschel, M.; Dragicevic, A.; Müller, M.; Hiemke, C.; Freymann, N.; Zobel, A.; Maier, W.; Rao, M.L. Impact of polymorphisms of cytochrome-P450 isoenzymes 2C9, 2C19 and 2D6 on plasma concentrations and clinical effects of antidepressants in a naturalistic clinical setting. Eur. J. Clin. Pharmacol. 2004, 60, 329-336. [CrossRef]

177. Yokono, A.; Morita, S.; Someya, T.; Hirokane, G.; Okawa, M.; Shimoda, K. The effect of CYP2C19 and CYP2D6 genotypes on the metabolism of clomipramine in Japanese psychiatric patients. J. Clin. Psychopharmacol. 2001, 21, 549-555. [CrossRef]

178. Smith, R.L.; Haslemo, T.; Refsum, H.; Molden, E. Impact of age, gender and CYP2C9/2C19 genotypes on dose-adjusted steady-state serum concentrations of valproic acid-A large-scale study based on naturalistic therapeutic drug monitoring data. Eur. J. Clin. Pharmacol. 2016, 72, 1099-1104. [CrossRef]

179. Cabaleiro, T.; López-Rodríguez, R.; Ochoa, D.; Román, M.; Novalbos, J.; Abad-Santos, F. Polymorphisms influencing olanzapine metabolism and adverse effects in healthy subjects. Hum. Psychopharm. Clin. 2013, 28, 205-214. [CrossRef]

180. Drugs@FDA: Drug Product ABILIFY (ARIPIPRAZOLE), NDA021436, Rebel Distributors Corp. Available online: https://www.accessdata.fda.gov/scripts/cder/daf/index.cfm?event=overview.process\&varApplNo= 021436 (accessed on 1 September 2019).

181. Drugs@FDA: Drug Product PERSERIS (Risperidone), NDA210655, Indivior Inc. Available online: https:// www.accessdata.fda.gov/scripts/cder/daf/index.cfm?event=overview.process\&varApplNo=210655 (accessed on 1 September 2019).

182. Findling, R.L.; Nucci, G.; Piergies, A.A.; Gomeni, R.; Bartolic, E.I.; Fong, R.; Carpenter, D.J.; Leeder, J.S.; Gaedigk, A.; Danoff, T.M. Multiple dose pharmacokinetics of paroxetine in children and adolescents with major depressive disorder or obsessive-compulsive disorder. Neuropsychopharmacology 2006, 31, 1274. [CrossRef]

183. Spigset, O.; Granberg, K.; Hägg, S.; Norström, Å.; Dahlqvist, R. Relationship between fluvoxamine pharmacokinetics and CYP2D6/CYP2C19 phenotype polymorphisms. Eur. J. Clin. Pharmacol. 1997, 52, 129-133. [CrossRef]

184. Gjestad, C.; Haslemo, T.; Andreassen, O.A.; Molden, E. 4 $\beta$-Hydroxycholesterol level significantly correlates with steady-state serum concentration of the CYP3A4 substrate quetiapine in psychiatric patients. Br. J. Clin. Pharmacol. 2017, 83, 2398-2405. [CrossRef]

185. Cuttle, L.; Munns, A.J.; Hogg, N.A.; Scott, J.R.; Hooper, W.D.; Dickinson, R.G.; Gillam, E.M. Phenytoin metabolism by human cytochrome P450: Involvement of P450 3A and 2C forms in secondary metabolism and drug-protein adduct formation. Drug. Metab. Dispos. 2000, 28, 945-950.

186. Brandl, E.J.; Chowdhury, N.I.; Tiwari, A.K.; Lett, T.A.; Meltzer, H.Y.; Kennedy, J.L.; Müller, D.J. Genetic variation in CYP3A43 is associated with response to antipsychotic medication. J. Neural. Transm. 2015, 122, 29-34. [CrossRef]

187. Kim, K.A.; Joo, H.J.; Lee, H.M.; Park, J.Y. Influence of ABCB1 and CYP3A5 genetic polymorphisms on the pharmacokinetics of quetiapine in healthy volunteers. Pharmacogenet. Genom. 2014, 24, 35-42. [CrossRef]

188. Krishnaswamy, S.; Hao, Q.; Al-Rohaimi, A.; Hesse, L.M.; von Moltke, L.L.; Greenblatt, D.J. UDP glucuronosyltransferase (UGT) 1A6 pharmacogenetics: II. Functional impact of the three most common nonsynonymous UGT1A6 polymorphisms (S7A, T181A, and R184S). J. Pharmacol. Exp. Ther. 2015, 313, 1340-1346. [CrossRef] 
189. Mei, S.; Feng, W.; Zhu, L.; Yu, Y.; Yang, W.; Gao, B.; Wu, X.; Zhao, Z.; Fang, F. Genetic polymorphisms and valproic acid plasma concentration in children with epilepsy on valproic acid monotherapy. Seizure 2017, 51, 22-26. [CrossRef]

190. Chang, Y.; Yang, L.Y.; Zhang, M.C.; Liu, S.Y. Correlation of the UGT1A4 gene polymorphism with serum concentration and therapeutic efficacy of lamotrigine in Han Chinese of Northern China. Eur. J. Clin. Pharmacol. 2014, 70, 941-946. [CrossRef]

191. Chung, J.Y.; Cho, J.Y.; Yu, K.S.; Kim, J.R.; Lim, K.S.; Sohn, D.R.; Shin, S.G.; Jang, I.J. Pharmacokinetic and pharmacodynamic interaction of lorazepam and valproic acid in relation to UGT2B7 genetic polymorphism in healthy subjects. Clin. Pharmacol. Ther. 2008, 83, 595-600. [CrossRef]

192. Wang, P.; Lin, X.Q.; Cai, W.K.; Xu, G.L.; Zhou, M.D.; Yang, M.; He, G.H. Effect of UGT2B7 genotypes on plasma concentration of valproic acid: A meta-analysis. Eur. J. Clin. Pharmacol. 2018, 74, 433-442. [CrossRef]

193. Milosheska, D.; Lorber, B.; Vovk, T.; Kastelic, M.; Dolžan, V.; Grabnar, I. Pharmacokinetics of lamotrigine and its metabolite N-2-glucuronide: Influence of polymorphism of UDP-glucuronosyltransferases and drug transporters. Br. J. Clin. Pharmacol. 2016, 82, 399-411. [CrossRef]

(C) 2019 by the authors. Licensee MDPI, Basel, Switzerland. This article is an open access article distributed under the terms and conditions of the Creative Commons Attribution (CC BY) license (http://creativecommons.org/licenses/by/4.0/). 